Review

\title{
Function of Nr4a Orphan Nuclear Receptors in Proliferation, Apoptosis and Fuel Utilization Across Tissues
}

\author{
Jacob A. Herring ${ }^{1,2,+}\left(\mathbb{D}\right.$, Weston S. Elison ${ }^{1,+}$ and Jeffery S. Tessem ${ }^{1, *(\mathbb{D}}$ \\ 1 Nutrition, Dietetics and Food Science Department, Brigham Young University, Provo, UT 84602, USA; \\ herrin06@gmail.com (J.A.H.); weston.elison@gmail.com (W.S.E.) \\ 2 Microbiology and Molecular Biology Department, Brigham Young University, Provo, UT 84602, USA \\ * Correspondence: Jeffery_tessem@byu.edu; Tel.: +1-801-422-9082 \\ + These authors contributed equally to this work.
}

Received: 1 October 2019; Accepted: 30 October 2019; Published: 1 November 2019

\begin{abstract}
The Nr4a family of nuclear hormone receptors is composed of three members-Nr4a1/Nur77, Nr4a2/Nurr1 and Nr4a3/Nor1. While currently defined as ligandless, these transcription factors have been shown to regulate varied processes across a host of tissues. Of particular interest, the Nr4a family impinge, in a tissue dependent fashion, on cellular proliferation, apoptosis and fuel utilization. The regulation of these processes occurs through both nuclear and non-genomic pathways. The purpose of this review is to provide a balanced perspective of the tissue specific and Nr4a family member specific, effects on cellular proliferation, apoptosis and fuel utilization.
\end{abstract}

Keywords: Nr4a1; Nr4a2; Nr4a3; nuclear hormone receptors; metabolism; fuel utilization; proliferation; apoptosis

\section{Introduction}

The Nr4a family consists of three members, Nr4a1 (Nur77/TR3/NGFI-B), Nr4a2/Nurr1 (TINUR/NOT) and Nr4a3/NOR1 (MINOR/CSMF). The three members have a high degree of sequence homology, with each containing a ligand-independent activation function-1 domain, transactivation domain necessary for transcriptional activity and cofactor binding, a DNA binding domain and a ligand binding domain containing a ligand-dependent AF-2 transactivation domain [1-3]. While currently defined as orphaned receptors with no known endogenous ligand, recent reports suggest that the Nr4a family's transcription factor function may be regulated through binding unsaturated fatty acids in the ligand binding domain [4-6].

The Nr4a family binds directly as monomers or homodimers to promoters of target genes that contain the NBRE (NGFIB Response Element-AAAGGTCA) motif [7]. The Nr4as can also form heterodimers and bind to the NuRE (Nur Response element-AAT(G/A)(C/T)CA) [8,9]. Finally, Nr4a1 and Nr4a2 have been shown to forms dimers with retinoid $X$ receptors and bind to the DR5 elements $[10,11]$. While there is a high degree of similarity between the three family members, the different members have differing affinity for co-factors and response elements, thus giving specificity to each [12].

The Nr4a family is widely expressed across various tissues [13]. The family was first discovered in the nervous system [14-17]. Nr4a's have been shown to be critical in the hematopoietic system [18], adipose tissue [19], liver [20], muscle [21] and $\beta$-cells [22], among other tissues [23,24]. In these tissues, the function of Nr4a family members fall into one of two categories. The majority of Nr4a activity is due to direct activation or repression of transcriptional target expression. Interestingly, a growing 
body of information is demonstrating a direct non-genomic role of Nr4a's through interaction with binding partners [25].

While the Nr4a's are associated with various cellular processes, three are of particular interest. The Nr4a's, across various tissue types, impinge on cellular proliferation, apoptosis and fuel utilization. These pathways are intimately connected. The cells ability and choice of macronutrients as a fuel source and their ability to utilize these molecules, greatly affects proliferation and cell survival. The type of metabolic pathways and choice of fuel oxidation is tightly coordinated with a cells ability to proliferate. Similarly, defective fuel utilization pathways or lack of oxidizable macronutrients, can impinges on apoptosis. Finally, signals that induce cell proliferation and apoptosis are in direct opposition to each other. This review will focus on the genomic and non-genomic Nr4a targets that allow for modulation of proliferation, apoptosis and fuel utilization.

\section{Proliferation}

The Nr4a subfamily is known to regulate cellular proliferation in a tissue dependent manner. Key genes shown to be regulated by Nr4a's include cyclins, cyclin dependent kinases and other ancillary cell cycle genes. Due to this, Nr4a1, Nr4a2 and Nr4a3 are potential therapeutic targets in many cancers, however their specific roles vary between tissues and among tumors from the same organ. The genes that have been shown to be transcriptionally regulated by the Nr4a's that are essential for cellular proliferation are summarized in Table 1.

Table 1. Genes regulated by the Nr4a's that are associated with cellular proliferation, defined by tissue of interest. References are given for each gene.

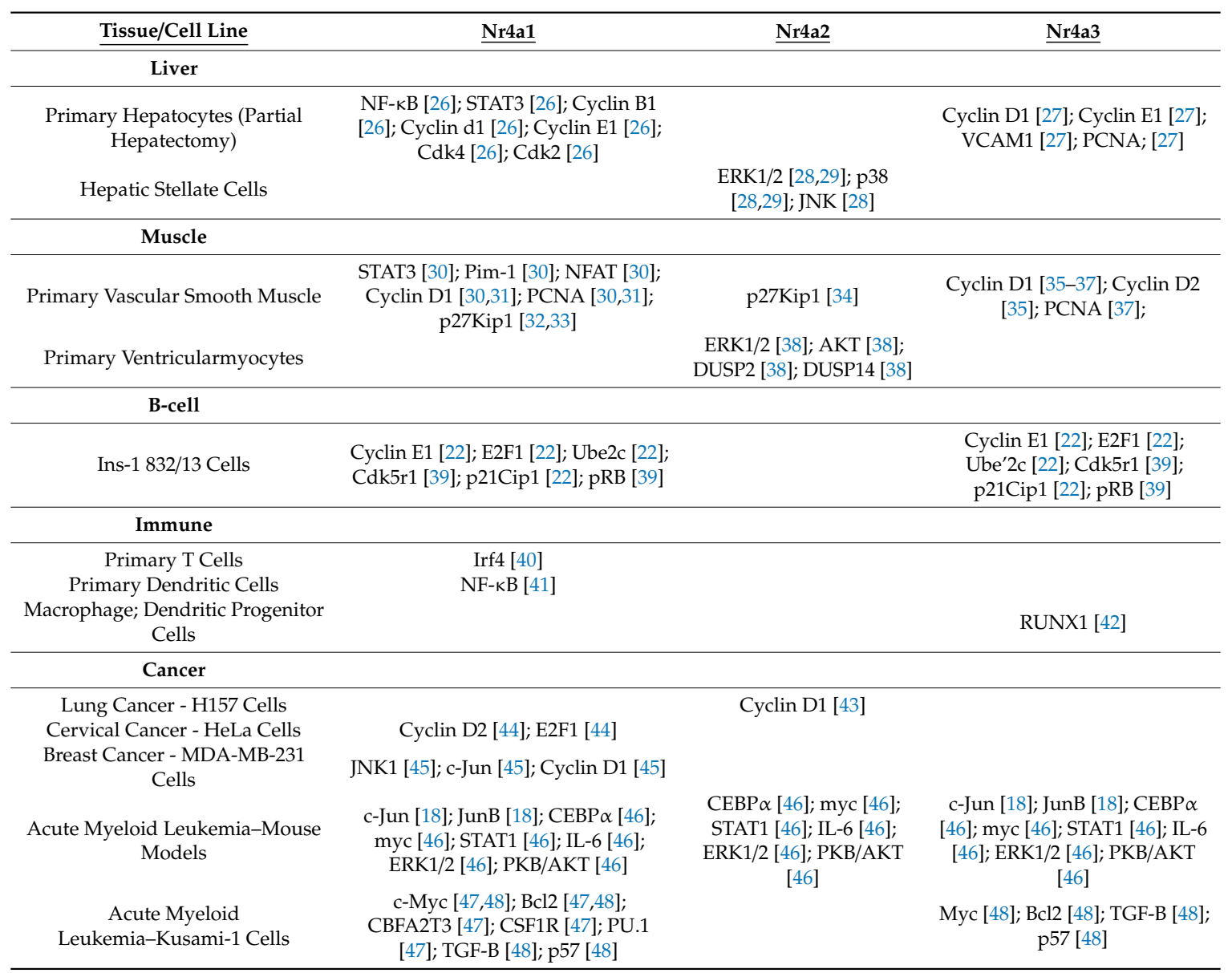


Table 1. Cont.

\begin{tabular}{|c|c|c|c|}
\hline Tissue/Cell Line & Nr4a1 & Nr4a2 & Nr4a3 \\
\hline \multicolumn{4}{|l|}{ Endothelium } \\
\hline $\begin{array}{l}\text { Primary Human Umbilical Vein } \\
\text { Endothelial Cells }\end{array}$ & $\begin{array}{c}\text { Cyclin A [49]; Cyclin D1 [49]; PCNA } \\
\text { [49]; E2F [49] }\end{array}$ & & \\
\hline \multicolumn{4}{|l|}{ Intestine } \\
\hline Intestinal Epithelium - IEC-6 Cells & p21Cip1 [50] & & \\
\hline Leiomyoma Smooth Muscle Cells & $\begin{array}{l}\text { TGF } \beta 3 \text { [51]; SMAD3 [51]; collagen } \\
\text { genes 1A1, 6A1, 6A2, and 16A1 [51] }\end{array}$ & $\begin{array}{c}\text { TGF } 33 \text { [51]; SMAD3 [51]; } \\
\text { collagen genes 1A1, 6A1, } \\
6 \mathrm{~A} 2 \text {, and 16A1 [51] }\end{array}$ & $\begin{array}{c}\text { TGF } 33 \text { [51]; SMAD3 [51]; } \\
\text { collagen genes 1A1, 6A1, 6A2, } \\
\text { and 16A1 [51] }\end{array}$ \\
\hline
\end{tabular}

\subsection{Liver}

Liver tissue has a remarkable ability to regenerate. Controlled cell proliferation is key in this process to regenerate tissue without becoming malignant. Hepatic stellate cell proliferation has also been identified as an issue in liver fibrosis. In both situations the Nr4a subfamily is a regulatory factor.

\subsubsection{Anti-Proliferation}

When subjected to partial hepatectomy Nr4a1 deficient mice generated by homologous recombination showed increase in NF- $\mathrm{KB}$ and STAT3 protein levels which in turn induced Cyclin B1, Cyclin D1, Cyclin E1, Cdk4 and Cdk2 expression within $24 \mathrm{~h}$, demonstrating that Nr4a1 limits regeneration in hepatocytes [26]. It is important to note, however, that recent findings have shown that the Nr4a1 knock out mouse used in this study (and others) expresses the N-terminal domain of Nr4a1 and that this is sufficient to bind and stabilize HIF1 $\alpha$ [52]. While no change in hepatocyte proliferation was demonstrated in this study, it does emphasize the need to validate these results in the floxed Nr4a1 model. In the hepatic stellate cell HSC-T6 cell line Nr4a2 inhibition by siRNA led to increased cell proliferation and decreased phosphorylation of the MAPK pathway members ERK1/2, p38 and JNK [28]. This result was supported by a marked increase in ERK1/2 and p38 phosphorylation observed in HSC-T6 cells overexpressing Nr4a2, along with decreased proliferation [29].

\subsubsection{Pro-Proliferation}

While Nr4a1 and Nr4a2 inhibit proliferation in liver tissues, Nr4a3 promotes proliferation in both hepatocytes and hepatic stellate cells. Mice treated with Nr4a3 shRNA were subjected to partial hepatectomy. Decreased expression of Cyclin D1, Cyclin E1, VCAM1 and PCNA were observed, as well as lower liver weight. Overexpression of $\mathrm{Nr} 4 \mathrm{a} 3$ increased expression of these same genes. Chromatin immunoprecipitation (ChIP) revealed that $\mathrm{Nr} 4 \mathrm{a} 3$ directly interacts with the Cyclin D1 promoter, demonstrating that it is a direct Nr4a3 target in hepatocytes [27]. In hepatic stellate cells TGF- $\beta 1$ was sufficient to drive activation and proliferation. TGF- $\beta 1$ was observed to increase expression of Nr4a3 and Nr4a3 inhibition impaired primary hepatic stellate cell proliferation, demonstrating Nr4a3's role in TGF- $\beta 1$ mediated hepatic stellate cell activation and proliferation [53]. As observed with hepatocytes, the Nr4a subfamily has opposing roles in controlling proliferation which may assist in balancing healthy benign growth.

\subsection{Muscle}

In smooth and cardiac muscle, proliferation is often associated with hypertrophy and disease pathogenesis such as atherosclerosis, restenosis and heart disease. Again, we see Nr4a's opposing roles in regulating this process. 


\subsubsection{Anti-Proliferation}

Vascular smooth muscle cells (VSMCs) have been used to study the Nr4a role in smooth muscle. VSMCs derived from pulmonary artery and saphenous vein, PDGF, 5-HT or stress were shown to cause proliferation. When Nr4a1 was overexpressed, it inhibited proliferation by blocking the STAT3/Pim-1/NFAT pathway members which decreased Cyclin D1 and PCNA expression [30-32]. Nr4a1 knock down increased stress induced proliferation and VSMCs from Nr4a1 deficient mice had increased proliferation [31,32]. Nr4a1 expression was increased in VSMCs treated with LDL-activated macrophages. Nr4a1 overexpression lead to lower proliferation rates, less tunica intima growth and induction of $\mathrm{p} 27^{\mathrm{Kip} 1}$, all of which ultimately blocked VSMC proliferation induced vessel narrowing [33]. In cardiomyocytes, Nr4a1 was found to block proliferation induced by neuropeptide $\mathrm{Y}$ which has been linked to cardiac hypertrophy [54].

Nr4a2 has a similar affect in neonatal tunica intima VSMCs as Nr4a1 does in other VSMCs. Nr4a2 knock down increased proliferation, while overexpression decreased proliferation by increasing p27 Kip1 expression [34]. Nr4a2 also inhibits proliferation in cardiac myocytes. Isoproterenol has been found to increase cardiomyocyte proliferation and when $\mathrm{Nr} 4 \mathrm{a} 2$ was overexpressed isoproterenol stimulated proliferation was decreased. The decreased proliferation was due to $\mathrm{Nr} 4 \mathrm{a} 2$ mediated increases in DUSP2 and DUSP14 expression which decreased ERK1/2 and AKT phosphorylation [38]. Together, Nr4a1 and Nr4a2 protect against cardiac hypertrophy and vessel narrowing due to stress and other causes such as atherosclerosis.

\subsubsection{Pro-Proliferation}

Nr4a3 again plays a counter role to Nr4a1 and Nr4a2 in VSMCs. PDGF and hypoxia induce Nr4a3 in VSMCs $[35,36]$. Nr4a3 promotes proliferation by inducing Cyclin D1, Cyclin D2 and PCNA, which effect was lost with siNr4a3 treatments [35-37]. While Nr4a1 and Nr4a2 are protective against hypertrophy and excess muscle tissue growth, Nr4a3 promotes proliferation. This proliferation may be beneficial in situations but in COPD induced hypoxia it is implicated in causing pulmonary hypertension [36],

\section{3. $\beta$-Cell}

\section{Pro-Proliferation}

Nr4a1 and Nr4a3 are both pro-proliferative in the $\beta$-cell. As $\beta$-cell loss and dysfunction are key aspects of diabetes pathology, $\beta$-cell proliferation would enable islet transplants and restored insulin secretion. Nkx6.1, a key $\beta$-cell transcription factor upregulates Nr4a1 and Nr4a3 expression. Nr4a1 and $\mathrm{Nr} 4 \mathrm{a} 3$ promote proliferation by increasing E2F1 which increases Cyclin E1 concentrations as well as by increasing Ube2c levels which degrades p21 ${ }^{\mathrm{Cip} 1}$ [22]. Cdk5r1 expression was also increased and is necessary for Nr4a1 and Nr4a3 driven $\beta$-cell proliferation, by increasing $\mathrm{pRb}$ phosphorylation and allowing E2F1 mediated increases in cell cycle gene expression [39].

\subsection{Immune System}

The Nr4a's have been extensively studied in the immune system. This subfamily plays an important role in regulating various immune cell types, in particular T cells. It is important to note, again, that many of these studies were completed using the Nr4a1 knock out animal that expresses NTD of Nr4a1, which has been shown to stabilize HIF1 $\alpha$ [52]. Some of the observed phenotypes of this mouse, particularly in the immune system, have not been found in the floxed Nr4a1 mice, that result in complete gene deletion. This mouse was often used in studies of acute myeloid leukemia (AML) 


\subsubsection{Pro-Proliferation}

The development of a Nr4a1 floxed, Nr4a2 floxed and Nr4a3 deficient mouse as a triple knockout of the Nr4a's showed their essential role in immune system regulation. These mice die within 21 days of birth with systemic autoimmunity, decreased Treg populations and decreased peripheral T cell proliferation [55]. They have also been found relevant individually in various immune cells types. In cultured neutrophils, Nr4a2 knock down decreases cell viability [56]. Nr4a3 knock down in mouse dendritic cells presents with decreased functionality, including decreased stimulation of $\mathrm{T}$ cell proliferation, which is a key step in the adaptive immune response [57].

\subsubsection{Anti-Proliferation}

Nr4a1 appears to be a negative regulator of $\mathrm{T}$ cell proliferation. CD8+ T cell proliferation was inhibited by Nr4a1, through binding to the Irf4 promoter and inhibiting transcription and ultimately Irf4's proliferative effects in T cells [40]. Nr4a1 knock down also increased dendritic cell function and T cell proliferation to the NF-kB-dependent inflammatory response [41]. While Nr4a3 promotes T cell proliferation through dendritic cells, mice with bone marrow transplanted from Nr4a3 deficient mice have more granulocyte-macrophage precursors and macrophage and dendritic cell progenitors, which is linked to increased plaque formation in atherosclerosis. Nr4a3 deficiency increased RUNX1 expression, a key transcription factor that promotes myeloid progenitor proliferation. Nr4a3 overexpression in turn decreased RUNX1 expression [42].

\subsection{Cancer}

Just as the Nr4a family members has different functions in different tissues, they behave differently in cancers of various origins. For some tumors the Nr4a's promote proliferation and in others they inhibit it, making modulation of these transcription factors a possible therapeutic target. Angiogenesis is also linked to the Nr4a subfamily, making it another target to limit tumor growth.

\subsubsection{Promotes Proliferation}

Nr4a1 and Nr4a2 promote lung cancer growth. H460 and Calu-6 cells overexpressing Nr4a1 had greater BrdU incorporation and Nr4a1 knockdown inhibited H460 cell growth [58]. SPC-A1 and H1299 cells had decreased proliferation when Nr4a1 was knocked down [59]. Nr4a2 knockdown in H157 cells blocked drug induced proliferation, while increased Nr4a2 expression correlated with increased Cyclin D1 expression [43]. Interestingly, Nr4a3 knockdown increased BrdU incorporation, tumor weight and decreased TUNEL positive cells in BRE-AS1 expressing H1299 cells [60]. This data suggests that while Nr4a1 and Nr4a2 increase lung cancer proliferation, Nr4a3 has an inhibitory effect.

$\mathrm{Nr} 4 \mathrm{a} 1$ has also been specifically identified to induce proliferation in colorectal cancer, renal cancer, medulloblastomas and thyroid cancer. Two groups showed that Nr4a1 knock down in HCT116 colorectal cancer cells decreased growth and viability [61,62]. Nr4a1 knock down decreased SW620 colony formation, while Nr4a1 overexpression had the opposite effect [63]. Treatment of RKO cells with the Nr4a1 agonist DIM-C-pPhOCH3 lead to decreased proliferation, in contrast with finding with other cell lines [64]. ACHN and 786-O renal cell lines showed that the Nr4a1 antagonists DIM-C-pPhOH and DIM-C-pPhCO ${ }_{2} \mathrm{Me}$ decreased cell numbers in a dose dependent manner and decreased ACHN xenograft size, suggesting that Nr4a1 also promotes renal cancer proliferation [65]. Nr4a1 overexpression increased medulloblastoma cell growth and viability, while Nr4a1 knock down decreased proliferation [66]. TT cells, a medullary thyroid carcinoma line, had decreased proliferation when Nr4a1 was knocked down [67].

Just as in the pancreatic $\beta$-cells, the Nr4a's promote proliferation in pancreatic cancer lines. Nr4a1 knockdown in Panc1 cells had decreased survival and Panc1, MiaPaCa-2 and L3.6pl cell lines treated with the Nr4a1 antagonist DIM-C-pPhOH presented with decreased proliferation [68]. Nr4a2 knock down in BxPC-3 pancreatic cancer cells had decreased cell growth and colony formation [69]. $\mathrm{Nr4a2}$ 
overexpression increase HTB-52 hepatocellular carcinoma proliferation [70]. Nr4a1 knock down in HeLa cells causes decreased viability and increased growth with Nr4a3 overexpression [71,72]. Nr4a1 is regulated by Pin1 in HeLa cells to express Cyclin D2 and E2F1 and drive proliferation [44]. MCF10A salivary gland cancer cells and mouse submandibular gland cells overexpressing Nr4a3 also showed increased proliferation [73]. Taken together, these data clearly demonstrate a subset of cancers in which Nr4a's induce proliferation. While this data shows how the Nr4a's are important for the growth of many cancers, there are many where the reverse is true.

\subsubsection{Inhibits Proliferation}

The roles of Nr4a1 and Nr4a3 have been studied extensively in AML, where they have similar function. Nr4a1 and Nr4a3 deficient mice develop AML with extensive myeloid cell proliferation due to decreased c-Jun and JunB expression [18]. Nr4a1 floxed and Nr4a3 deficient mice created a less severe AML phenotype but still showed increased hematopoietic stem cell proliferation and decreased bone marrow cellularity. In this state $\mathrm{CEBP} \alpha$, an AML tumor suppressor, was down regulated and Myc genes, STAT1, inflammatory proliferation genes like IL-6 and phosphorylation of PKB/AKT and ERK1/2 all increased [46]. Another study used both $\mathrm{Nr}_{4} \mathrm{a}^{-/-} \mathrm{Nr}^{-13} 3^{+/-}$and $\mathrm{Nr} 4 \mathrm{a}^{+/-} \mathrm{Nr} 4 \mathrm{a} 3^{-/-}$mice, which increased neutrophil and monocyte proliferation, as well as an increased the BrdU incorporation level in hematopoietic stem cells, multipotent progenitor cells and myeloid progenitors [74]. These studies show that loss of Nr4a1 and $\mathrm{Nr} 4 \mathrm{a} 3$ results in impaired immune regulation as well as AML progression.

Studies have further examined the roles of Nr4a1 and Nr4a3 in AML cell lines and other immune cell cancers. Nr4a1 downregulates proliferation associated genes such as c-MYC, BCL2, CBFA2T3 and CSF1R and the myeloid transcription factor PU.1 in Kasumi-1 cells [47]. Nr4a1 and Nr4a3 overexpression decreased Kasumi-1 proliferation and cell viability. Analysis showed that $\mathrm{Myc}$ and $\mathrm{Bcl} 2$ were down regulated by Nr4a1 and Nr4a3 while TGF-B was upregulated, increasing p57 levels [48]. The pharmacological compounds DHE and ALP are sufficient to block AML tumor growth by inducing Nr4a expression and down regulating c-Myc [75] Nr4a3 overexpression decreased SuDHL4 B cell line proliferation and xenograph growth. Validating this, Nr4a3 knock down increased cell viability of the U2932 and SuDHL4 cell lines [76]. The observed AML phenotypes in multiple Nr4a knockout mice draws a strong tie to their role in the immune system these genes play and, in a manner, that none of the other cancer tissues can quite match, making this a strong area for continued research.

In addition to their role of inhibiting proliferation in hematopoietic based malignancies Nr4a1 overexpression in UM-UC-3 bladder cancer cells decreased androgen stimulated proliferation, while Nr4a1 knockdown increased growth [77]. Similarly, Nr4a1 overexpression in Ishikawa cells, an endometrial cancer line, decreased proliferation, while Nr4a1 knock down increased proliferation [78]. These data clearly demonstrate a subpopulation of tumors where Nr4a expression inhibits proliferation.

\subsubsection{Varied Results}

While the Nr4a subfamily may be clear targets in the malignancies discussed this far, there are a few cancers where their role is conflicting, making them less ideal therapeutic targets. The effects of the Nr4a subfamily on breast cancer proliferation is not consistent. MCF-7, MDA-MB-231 and SKBR3 cell lines had decreased cell number and tumor weigh when treated with the Nr4a1 antagonists DIM-C-pPhCO2Me and DIM-C-pPhCN, as well as with Nr4a1 knock down [79]. MDA-MB-231 cells also have decreased proliferation with Nr4a1 overexpression due to JNK1, c-Jun and Cyclin D1 downregulation [45]. MCF-10A cells had no change in proliferation when overexpressing Nr4a1 and measurements across many breast cancer tumors found Nr4a1 expression to be inconsistent, suggesting that Nr4a1's role in breast cancer may be tumor specific [80]. MDA-MB-468 and MDA-MB-231 lines also had lower xenograft weights with Nr4a2 knockdown [81].

Nr4a's role in prostate cancer is also conflicting. Nr4a1 knock down decreased PC 3 cell line proliferation [82], DU145 and PC3 cells were also Nr4a3 sensitive, with $\mathrm{Nr} 4 \mathrm{a} 3$ overexpression decreasing proliferation and tumor size and $\mathrm{Nr} 4 \mathrm{a} 3$ proliferation increasing proliferation [83]. These data suggest 
that $\mathrm{Nr} 4 \mathrm{a} 1$ is pro-proliferative while $\mathrm{Nr} 4 \mathrm{a} 3$ is anti-proliferative. This may be similar to primary tissue where Nr4a1 and Nr4a3 play opposing roles to regulate proliferation.

\subsubsection{Angiogenesis}

While the Nr4a's role in tumor proliferation is being studied as a therapeutic target it is also being examined for their role in angiogenesis and endothelial cell proliferation. VEGF-A induces Nr4a1 expression and Nr4a1 overexpression in the absence of VEGF-A is sufficient to induce primary umbilical vein endothelial cell proliferation to the same level of VEGF-A alone. Furthermore, Nr4a1 mutants blocked the VEGF-A mediated proliferation effect. Nr4a1 upregulates Cyclin A, Cyclin D1, PCNA and E2F in vasculature endothelial cells [49]. Histamine and serotonin are both sufficient to induce endothelial cell proliferation, however cells deficient in Nr4a1 are resistant to these treatments [84]. Nr4a1 knockdown decreased VEGF induced DNA synthesis in human umbilical vein endothelial cells and when Nr4a1 was knocked down in the presence of VEGF there were fewer vessels per square millimeter in microscopic analysis, suggesting that VEGF acts through Nr4a1 in angiogenesis [85]. As angiogenesis is vital for a tumor expansion and metastasis, it be a potential target to limit the tumor growth regardless of tissue of origin.

\subsection{Other Tissues of Note}

\subsubsection{Pro-Proliferation}

Among all of the tissues included there are a few more to be noted where the Nr4a's have an effect. In an intestinal ischemia mouse model, the mice treated with the Nr4a2 activator C-DIM12 presented increased Ki67+ cells and better recovery [86]. Nr4a1 knock down in IEC-6 intestinal epithelial cells had decreased proliferation, while overexpression increased proliferation by inhibiting p21 ${ }^{\mathrm{CIP} 1}$ expression [50]. Nr4a1 also promotes spermatogonium development in human primary Sertoli cells by inducing expression of GDNF [87]. Synoviocyte proliferation is part of the pathogenesis of arthritis. Nr4a2 overexpression increased K4IM synoviocyte proliferation, while Nr4a2 knock down decreased proliferation, indicating $\mathrm{Nr} 4 \mathrm{a} 2$ as a possible arthritis regulator [88].

\subsubsection{Anti-Proliferation}

Knockdown of Nr4a1 and Nr4a2 by in mesenchymal stromal cells increased cell cycle progression and overexpression impeded proliferation by inducing a G1 cell cycle block [89]. Nr4a1 knock down increased NIH3T3 fibroblast cell growth [90]. Overexpression of each of the Nr4a genes decreased leiomyoma smooth muscle cells, part of uterine fibroids, proliferation rate by decreasing TGF $\beta 3$, SMAD3 and collagen genes 1A1, 6A1, 6A2 and 16A1 expression [51].

\subsubsection{Varied Results}

Neural tissue presented mixed results with regards to $\mathrm{Nr} 4 \mathrm{a} 2$ and proliferation. Nr4a2 overexpression in primary neural stem cells from the olfactory bulb led to fewer $\mathrm{BrdU}^{+}$cells but when rat adult hippocampal neural precursors were treated with the Nr4a2 agonist amodiaquine, BrdU incorporation and viability increased [91,92].

These data clearly demonstrate that the Nr4a's play a critical role in regulating cellular proliferation. The Nr4a's clearly have a tissue specific effect, where they may induce proliferation in one tissue while inhibiting in another. This suggests differences in chromatin accessibility, either due to changes in binding partner expression, post translational modification or chromatin modifications. These data support the ongoing studies to understand mechanisms by which the Nr4a's induce or inhibit proliferation as potential therapeutic intervention for various conditions. 


\section{Apoptosis}

The second major function of the Nr4a nuclear hormone receptors is regulating cellular apoptosis. The role of the Nr4a's in controlling apoptosis is complex and present across several tissues. This section will focus on the role of the Nr4a's on apoptosis, focusing on transcriptional changes in the intrinsic and extrinsic apoptosis pathways, as well as non-genomic functions of the Nr4a nuclear receptors that impinge on apoptosis. The genes that are transcriptionally regulated by the Nr4a's that are essential for cellular apoptosis are summarized in Table 2.

Table 2. Genes regulated by the Nr4a's that are associated with cellular apoptosis, defined by tissue of interest. References are given for each gene.

\begin{tabular}{|c|c|c|c|}
\hline Tissue/Cell Line & Nr4a1 & $\underline{\mathrm{Nr} 4 \mathrm{a} 2}$ & $\underline{\mathrm{Nr} 4 \mathrm{a} 3}$ \\
\hline \multicolumn{4}{|l|}{ Liver } \\
\hline HepG2 & DNA-PKcs [93] & ERK1/2 [29]; p38 [29]; Ku80 [93] & \\
\hline \multicolumn{4}{|l|}{ Muscle } \\
\hline Primary Vascular Smooth & & & cIAP2 [94] \\
\hline \multicolumn{4}{|l|}{ B-cell } \\
\hline $\begin{array}{l}\text { Min6 } \\
\text { Primary Mouse Islets }\end{array}$ & $\begin{array}{c}\text { Survivin [95]; CHOP [95] } \\
\text { WT1 [96]; BCL-2 [96]; } \\
\text { SOD1 [96] }\end{array}$ & & \\
\hline \multicolumn{4}{|l|}{ Immune } \\
\hline T Cells & Fasl [97] & & \\
\hline \multicolumn{4}{|l|}{ Cancer } \\
\hline $\begin{array}{c}\text { Pancreas Cancer - Panc-1, } \\
\text { L.3.6pL } \\
\text { C57BL/6 Nude mice } \\
\text { Colon }\end{array}$ & $\begin{array}{c}\text { TXNDC5 [157 } \\
\text { TRAIL [64]; PDCD1 [64] } \\
\text { TRAIL [64]; PDCD1 [64] }\end{array}$ & & \\
\hline \multicolumn{4}{|l|}{ Brain } \\
\hline Neurons & & $\begin{array}{c}\text { Adcyap1 [98]; Sod1 [98]; C-flar } \\
\text { [98] }\end{array}$ & \\
\hline \multicolumn{4}{|l|}{ Umbilical Cord } \\
\hline HUC-F2 & & Caspace3 [99]; Caspase8 [99] & \\
\hline \multicolumn{4}{|l|}{ Kidney } \\
\hline Hek293 & $\begin{array}{l}\text { TRAP } \gamma \text { [100]; Hif1- } \alpha \\
\text { [101]; pVHL [101] }\end{array}$ & Hif1- $\alpha$ [101]; pVHL [101] & PARP-1 [102] \\
\hline \multicolumn{4}{|l|}{ Bone } \\
\hline U2OS & & Poly-ADP-Ribose [103] & \\
\hline
\end{tabular}

\subsection{Intrinsic Apoptotic Pathway}

There are two main methods that regulate apoptosis in mammalian cells. They are the intrinsic pathway or mitochondrial signaled apoptosis pathway and the extrinsic pathway or death-receptor mediated pathway. Both involve amplification of proteolytic cascades which leads to apoptosis [104,105]. The intrinsic pathway is activated by cellular stressors that increase mitochondrial permeability. These stressors are recognized by several internal proteins that signal to the mitochondria. The Bcl-2 family is most commonly used in this interaction. The ratio of pro-apoptotic and anti-apoptotic Bcl-2 proteins regulate the pathway. When pro-apoptotic Bcl-2 proteins accumulate, they translocate to the mitochondria and form pores in the mitochondrial membrane. This causes cytochrome c release, caspase-9 activation and eventual cell death [106-108]. Understanding how the Nr4a receptor family regulate these pathways will be addressed. 


\subsubsection{Liver}

Liver fibrosis is a wound healing response caused by over accumulation of extracellular matrix proteins. This leads to decreased liver function and eventually cirrhosis [109]. Nr4a2 overexpression in HSC decreases liver fibrosis [29]. Nr4a2 regulates ERK1/2 and p38 expression in HSC leading to apoptosis. Rats overexpressing Nr4a2 treated with dimethylnitrosamine, which induces liver fibrosis, are protected from liver damage. Nr4a2 overexpression induces apoptosis in the cirrhotic tissue [29]. This shows that Nr4a2 protects healthy liver tissue from becoming fibrotic while also inducing apoptosis in fibrotic tissue via the ERK1/2 and p38 pathway.

\subsection{2. $\beta$-Cell}

The occurrence of type 2 diabetes is closely linked to the loss of pancreatic $\beta$-cells and their function $[22,110]$. Pancreatic $\beta$-cells are sensitive to hyperglycemia and hyperlipidemia, which alter $\mathrm{Ca}^{2+}$ concentrations in pancreatic islets, leading to increased endoplasmic reticulum (ER) stress and eventually apoptosis via the intrinsic apoptosis pathway $[110,111]$. Thapsigargin (TG) and palmitic acid (PA) are known inducers of $\beta$-cell ER stress. MIN6 cells and primary C57BL/6J mouse islets treatment with TG and PA caused increases in Nr4a1 and C/EBP homologous protein (CHOP) levels in a time-dependent manner [95]. Nr4a1 overexpression in MIN6 cells and islets increased cell survival rates as measured by MTT, TUNEL assay and Caspase3 cleavage. Survivin protein binds to pro-caspase 3 and prevent Caspase 3 activation, reducing cell death [112]. Nr4a1 directly regulates Survivin expression through promoter binding. Nr4a1 knockdown in MIN6 cells treated with TG and PA caused decreased cellular viability via decreased Survivin expression, leading to increased Caspase 3 activation and increased $\mathrm{CHOP}$ protein. This suggests that $\mathrm{Nr} 4 \mathrm{a} 1$ protects the $\beta$-cell and primary islets against ER stress by directly upregulating Survivin and indirectly downregulating CHOP.

Proper $\beta$-cell function is central to the pathogenesis of type-2 diabetes mellitus [113-115]. Oxidative stress is commonly found in the $\beta$-cells of diabetic patients and prevention of this stress is protective in pancreatic $\beta$-cells [116]. MIN6 cells treated with $\mathrm{H}_{2} \mathrm{O}_{2}$ increases Nr4a1 levels and increased Caspase3 cleavage [96]. Nr4a1 overexpression in MIN6 and primary mouse islets cells protects from reactive oxygen species (ROS) damage and increases cellular viability. Expression experiments determined that Nr4a1 overexpression upregulated anti-apoptotic genes (WT1 and BCL-2) and ROS scavenger genes (SOD1). Genetic analysis showed a NBRE binding sequence in the WT1 promoter, ChIP showed that Nr4a1 directly regulates WT1 expression and WT1 knockdown decreased BCL-2 and SOD1 expression. Therefore, Nr4a1 protects primary islets from ROS by directly altering WT1 expression and indirectly increasing BCL-2 and SOD1 expression.

$\mathrm{Nr} 4 \mathrm{a} 3$ expression has recently been shown to correlate with cytokine mediated $\beta$-cell death [10]. Nr4a3 was upregulated in Ins-1 cells and human islets cultured with IL-1 $\beta$ and TNF $\alpha$. This resulted in increased apoptosis as measured by TUNEL staining, DNA fragmentation and cytochrome c release. Knock down of Nr4a3 impaired cytokine mediated apoptosis and re-expression of Nr4a3 induced apoptosis. Together these data suggest that $\mathrm{Nr} 4 \mathrm{a} 1$ is anti-apoptotic and $\mathrm{Nr} 4 \mathrm{a} 3$ is pro-apoptotic in the pancreatic $\beta$-cells.

\subsubsection{Cancer}

As previously stated, cytochrome c contributes to apoptosis by initiating the caspase cascade upon its release into the cytosol [117-119]. Nr4a1 knockdown significantly decreased apoptosis in prostate cancer cells. A GFP-Nr4a1 fusion protein was used to track location of Nr4a1 during apoptotic treatment. Nr4a1 translocates from the nucleus to the mitochondria when treated with several apoptotic drugs [120]. Prostate cancer cells treated with leptomycin B, which blocks nuclear export [121] and apoptotic drugs, showed decreased cytochrome $\mathrm{c}$ release due to decreased Nr4a1 mitochondrial binding [120]. Interestingly, deletion of the DNA binding domain (DBD) of Nr4a1 had no effect on cytochrome c release. It was determined that a 152-amino acid residue from the 
$\mathrm{NH}_{2}$-terminus and 96 amino acids from the $\mathrm{COOH}$-terminus are critical for $\mathrm{Nr} 4 \mathrm{a} 1$ mitochondrial targeting. When Nr4a1 was altered to target the plasma membrane [122] or the ER [123] apoptosis was decreased. Similar experiments were done in rats exposed to ischemia in vivo and in primary melanoma tissue [124,125]. Nr4a1 levels were decreased in primary melanoma tissue, possibly leading to protection from apoptotic treatments. Nr4a1 co-localizes with Bcl-2 in the mitochondria in prostate cancer cells, melanoma cells and gastric cancer cells [125-128] These data confirm that Nr4a1 has extra-nuclear functions, independent of DNA binding, as part of the intrinsic apoptotic pathway to induce cytochrome $\mathrm{c}$ release. Furthermore, several studies show that the Nr4a family have significant non-genomic function in the body as described [52,93,100-103,129]. Taken together, this shows that while the Nr4a's primarily function as genetic regulators they have non-genomic functions that are integral for cellular apoptosis and function. The use of the Nr4a1 floxed mouse and the Nr4a1 full body NTD-Nr4a1 mouse could be leveraged to better determine the non-genomic roles of Nr4a1 [101].

Post-translational modifications (PTMs) alter protein function $[130,131]$. Phosphorylation of Nr4a1 at Ser351 by Akt blocks mitochondrial targeting in H460 lung cancer cells and BGC-823 gastric cancer cells $[127,132,133]$. Interestingly, in BGC-823 cells Ser351 phosphorylation blocks both nuclear export of Nr4a1 and mitochondrial targeting of cytosolic Nr4a1. The mitochondrial interaction of Nr4a1 in these cancer cells was independent of its DBD, supporting previous data [120]. However, in BGC-823 cells Akt phosphorylation only occurred on the N-terminus of Nr4a1 [127]. Nuclear phosphorylation of Nr4a1 at Ser105 induces export and mitochondrial targeting [133,134]. Akt phosphorylation of Nr4a1 decreases apoptosis and cytochrome c release. Together, these data show that Nr4a1 is regulated by PTMs and that it is integral for apoptosis in cancer cells.

Acute myeloid leukemia is caused by an increase in immature myeloid progenitors and the emergence of leukemia initiating cells. Properties and structure of these cells makes AML difficult to treat. The Nr4a family control regulation of hematopoietic stem cell development [18]. Nr4a1 and $\mathrm{Nr} 4 \mathrm{a} 3$ acute expression is sufficient to decrease cellular viability in Kasumi-1 cell lines in a DNA binding domain dependent manner [48]. Nr4a1 and Nr4a3 have a strong inverse correlation to several MYC target genes in Kasumi-1 cells, including Bcl-2 and TNF [48]. Nr4a1 and Nr4a3 also regulate several different types of lymphoma, including non-Hodgkin's and B-cell. Human samples from cancer patients were analyzed for the Nr4a family and their downstream targets [135-137]. They found that cytoplasmic localization of Nr4a1 increased overall life expectancy of B-cell lymphoma patients through decreased caspase 3 cleavage and ERK1/2 levels [136]. Furthermore, both Nr4a1 and Nr4a3 levels were decreased in Non-Hodgkin's lymphoma, as well as FasL and TRAIL proteins, which could result in decreased intrinsic and extrinsic apoptotic signaling. Decreased Nr4a1 showed a significant association with poor cancer-specific survival, suggesting that Nr4a1 could be used as an independent prognostic indicator [135]. In SuDHL4 lymphoma cell lines, Nr4a1 overexpression led to increased cleaved caspase 3/7 levels and Annexin V showing an increase an apoptosis. This increase in apoptosis was caused by increased pro-apoptotic proteins, TRAIL, Bim and Puma, suggesting that Nr4a1 acts as an activator on genes responsible for apoptosis in lymphoma cells [135]. Nr4a3 was also found to bind to $\mathrm{p} 53$ and induce apoptosis in breast and lung cancer cells and that high levels of Nr4a3 correlated to better survival in these patients [137]. This shows that Nr4a1 and $\mathrm{Nr} 4 \mathrm{a} 3$ controls induction of apoptosis in different lymphoma cells.

\subsection{Extrinsic Apoptotic Pathway}

The extrinsic pathway begins with attachment of ligands to the extracellular domain of transmembrane proteins [138]. Ligand binding signals the intracellular death domain to bind with its corresponding protein motif. These adaptor proteins have a death effector domain which interacts with the death effector domain of procaspase- 8 . This interaction activates a death inducing signaling complex which catalyzes procaspase-8. Cleaved caspase-8 activates effector caspases which cause cell death by damaging the nucleus and other internal organelle [139-141]. 


\subsubsection{Muscle}

The inhibitor of apoptosis (IAP) family of proteins are critical in the regulation of apoptosis [142,143]. IAPs promote pro-survival signaling pathways and prevent apoptosis by interfering with caspase activity [143]. Nr4a3 overexpression protects vascular smooth muscle cells (VSMC) from apoptotic treatment. Hypoxia and the hypoxia mimetic cobalt chloride increased Nr4a3 levels in VSMC. This regulation was determined to be dose and time dependent. Nr4a3 directly regulates cIAP2 expression in VSMC through an NBRE binding site [94]. Knockdown of cIAP2 removes Nr4a3 driven protection. This shows that Nr4a3 protects VSMC from caspase activity by increasing expression of cIAP2.

\subsubsection{Immune System}

The Nr4a family also induces apoptosis in certain cell types. This has been well documented in T-cells. Induced apoptosis in A04H5.3 T-cells causes an increase in Nr4a1 RNA and protein expression and Nr4a1 dominant negative mutant was protected from cell death [144]. This was also confirmed in vivo using C57Bl/6 transgenic mice which constitutively expressed wildtype $\mathrm{Nr} 4 \mathrm{a} 1$ or the dominant negative mutant. They found that Nr4a1 dominant negative mice had lower levels of thymocytes, mature $T$ cells and decreased tolerance while the constitutively expressed wildtype mice were unable to perform antigen-induced negative selection of the T cells $[145,146]$. While the direct Nr4a1 target genes are still unknown in T-cells there is a correlation between FasL and Nr4a1 expression [97,147]. This shows a complex regulatory network in the Nr4a family that has not been fully determined.

Macrophage treated with LPS and simvastatin undergo a caspase independent apoptotic pathway [148]. Treating RAW 264.7 cells with farnesyl transferase inhibitors decreased LPS and simvastatin mediated apoptosis, suggestion that farnesyl proteins are responsible for apoptosis [149]. Simvastatin treatment alone gradually increases Nr4a1 mRNA levels overtime. RAW 264.7 cells treated with a dominant negative Nr4a1 showed significantly decreased DNA fragmentation and decreased disruption of mitochondrial membrane potential. This is caused by decreased levels of BAX translocation to the mitochondria in cells treated with farnesyl inhibitors [150]. This data shows that $\mathrm{Nr} 4 \mathrm{a} 1$ is crucial for non-caspase driven apoptosis pathway and that N4a1 plays a role in mitochondrial membrane potential in RAW 264.7 cells.

T-cells expressing chimeric antigen receptors (CAR) targeting human CD19 have exhibited impressive clinical efficacy against B cell cancers [151]. CAR T-cell have been less effective against solid tumors due to an increase in antigen stimulation and decrease effector function [152]. CAR T-cells with deficiencies in Nr4a1, Nr4a2 and Nr4a3 showed improved tumor cell death and increased effector function [153]. This improvement is caused by downregulation of CD8 ${ }^{+} \mathrm{T}$-cell inhibitory receptors PD-1, TIM3 and CTLA4. This function is important for healthy T-cell formation but it is inhibitory for CAR T-cells and leads to dysfunction and exhaustion. This shows that the Nr4a family plays in important role for CAR T-cell function against solid tumors.

\subsubsection{Other}

The effect of the Nr4a family over the extrinsic apoptosis pathway is very complex and varies depending on cell type and stimulus. $\mathrm{H}_{2} \mathrm{O}_{2}$ treatment is commonly used to measure cellular viability as ROS is sufficient to induce apoptosis $[98,154,155]$. Treatment of human umbilical cord fibroblast (HUC-F2) with $\mathrm{H}_{2} \mathrm{O}_{2}$ for $4 \mathrm{~h}$ increased Nr4a1 mRNA levels. Knockdown of Nr4a1 decreased cellular viability by increased activated caspase 3 and 8 levels [99]. Therefore, in HUC-F2 cells Nr4a1 functions in a protective, anti-apoptotic role. Similar data have been seen in several different human cancer cell lines, including Panc-1, L3.6pl, MCF7 and RKO, using both siRNA and 1,1-bis(3'-indolyl)-1-( -anisyl) methane treatments $[68,156,157]$. Nr4a1 directly regulates TXNDC5 expression which protects Panc-1 cells from ER-stress mediated apoptosis [157]. In primary colon tumor tissue, Nr4a1 expression levels are elevated [68]. Although, Nr4a1 directly regulates tumor necrosis factor-related apoptosis-inducing ligand (TRAIL) protein and PDCD1 in RKO cells. Nr4a1 knockdown in C57BL/6 nude mice with RKO 
cells xenografts had decreased tumor volume and final tumor weight [64]. This shows that Nr4a1 plays an important role across different tissues by protecting cells from apoptosis.

These data clearly indicate that the Nr4as play a critical role in regulating apoptosis across several different tissues. There does not appear to be a tissue specific effect of these proteins or consensus across the protein family in response to similar treatment. What we can conclude is that their regulatory network is complicated and more research needs to be done fully illuminate their function in regulating apoptotic pathways and future use for therapeutic treatments.

\section{Fuel Utilization}

A third major function of the Nr4a nuclear hormone receptors is controlling expression of genes associated with fuel utilization. The function of the Nr4a's in controlling cellular fuel utilization is a function conserved from C. elegans to man, where studies have shown its function in glucose metabolism, lipid metabolism, TCA cycle and oxidative phosphorylation. This section reviews the role of the Nr4a's in fuel utilization, focusing on effects in glucose metabolism, lipid metabolism and mitochondrial function. The genes regulated by the Nr4a's that are essential for fuel utilization are summarized in Table 3.

Table 3. Genes regulated by the Nr4a's that are associated with fuel utilization, defined by tissue of interest. References are given for each gene.

\begin{tabular}{|c|c|c|c|}
\hline Tissue/Cell Lines & Nr4a1 & $\mathrm{Nr} 4 \mathrm{a} 2$ & $\underline{\mathrm{Nr} 4 \mathrm{a} 3}$ \\
\hline \multicolumn{4}{|l|}{ Liver } \\
\hline Primary Hepatocytes & $\begin{array}{l}\text { Fbp1 [20,158]; Bpgm [20]; Pgk1 [20]; } \\
\text { Eno3 [20,158,159]; G6pc [20,158,159]; } \\
\text { Fbp2 [158]; Glut 2 [158]; Pgc1a [20]; } \\
\text { Gyk [20]; PEPCK [159]; PC [159]; Lpl } \\
\text { [20]; Ehhadh [20]; SREBP1c [20,160]; } \\
\text { FAS [20,160]; Gpam [160]; G6Pase } \\
\text { [20]; Lipin1 [20]; Pdk4 [20] } \\
\text { G6pc [161]; PEPCK [161]; CPT1a [162]; }\end{array}$ & $\begin{array}{l}\text { Fbp1 [158]; Eno3 } \\
\text { [158,159]; G6pc [158,159]; } \\
\text { Fbp2 [158]; Glut } 2 \text { [158]; } \\
\text { PEPCK [159]; PC [159]; } \\
\text { CPT1a [162] }\end{array}$ & $\begin{array}{l}\text { Fbp1 [158]; Eno3 [158,159]; G6pc } \\
\text { [158,159]; Fbp2 [158]; Glut } 2 \text { [158]; } \\
\text { PEPCK [159]; PC [159]; }\end{array}$ \\
\hline \multicolumn{4}{|l|}{ Muscle } \\
\hline Primary Muscle & $\begin{array}{l}\text { Glut4 [20,163-165]; Pfkm [163]; Pygm } \\
\text { [167, Eno3 [20,163,166-168],Bpgm } \\
\text { [166,167]; Pgk1 [166,167]; CD36 [164]; } \\
\text { AdipoR2 [164]; UCP2 [164]; UCP3 } \\
\text { [164]; NADH-TR [165]; Cox1 [165]; } \\
\text { Sdhb [165] }\end{array}$ & & $\begin{array}{l}\text { HK1 [169]; Pfk-1 [169]; GAPDH [169]; } \\
\text { Pgam2 [169]; Eno3 [169]; Pkm } \\
\text { [169],MDH [169]; AST [169]; Pdh } \\
\text { [169]; Glut4 [169]; HK2 [169]; Stbd1 } \\
\text { [169]; Gys1 [169]; PPP1R1A [169]; } \\
\text { CRAT [169]; ACSL [169]; ACDH [169]; } \\
\text { ECH [169]; 3-KCT [169]; Idh3 [169]; } \\
\text { Ogdh [169]; Scs [169]; Sdhb [169]; Fh } \\
\text { [169]; Mdh [169]; Atp5a1 [170]; Uqcr2 } \\
\text { [170]; Cox1 [170]; Sdhb [170]; and } \\
\text { Ndufb8 [170] }\end{array}$ \\
\hline Cadiomyocyte & GFPT2 [171] & & \\
\hline $\mathrm{C} 2 \mathrm{C} 12$ & $\begin{array}{l}\text { Glut4 [172]; Pfkm [172]; Pygm [172]; } \\
\text { Eno3 [172]; Aldo1 [172]; PHKG1 [172]; } \\
\text { PGAM2 [172] }\end{array}$ & & $\begin{array}{l}\text { PGC-1a [21]; PGC-1b [21]; Lipin1a } \\
\text { [21]; Pdp1c [21]; Pdp1r [21]; Ucp3 } \\
\text { [168]; }\end{array}$ \\
\hline \multicolumn{4}{|l|}{ Adipose } \\
\hline 3T3-L1 & SREBP1c [173]; PPARg [173] & & Glut4 [174] \\
\hline HIB-1B & Ucp1 [175,176] & & Ucp1 [175,176]; \\
\hline \multicolumn{4}{|l|}{$\beta$-cell } \\
\hline Ins-1 832/13 & $\begin{array}{l}\text { Eno1 [177,178]; Eno3 [178]; GAPDH } \\
\text { [178]; Pgk [178]; Idh3g [177]; Sdhb } \\
\text { [177] }\end{array}$ & & Eno1 [177]; Idh3g [177]; Sdhb [177]; \\
\hline MIN-6 & Eno3 [179] & & Eno3 [179] \\
\hline
\end{tabular}


Table 3. Cont.

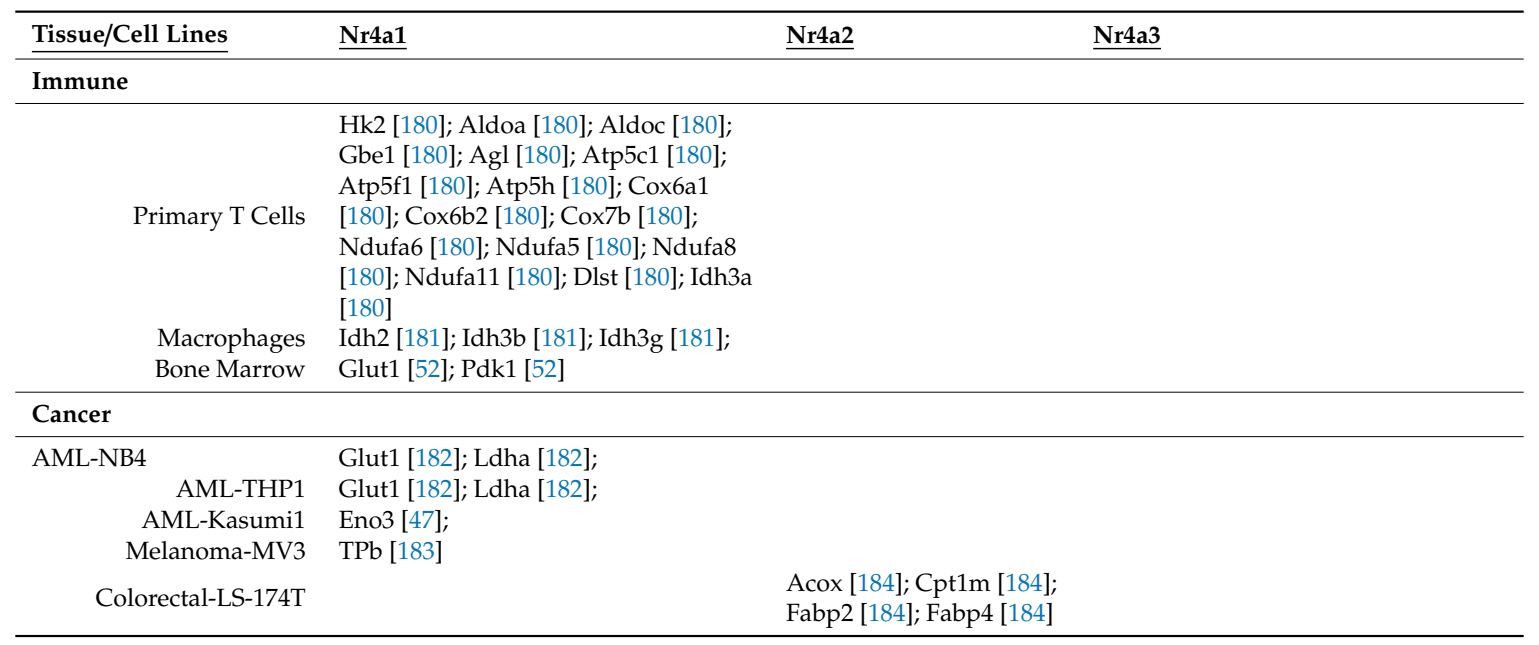

\subsection{Glucose Metabolism}

The C. elegans Nr4a ortholog is NHR-6. NHR-6 has preferential binding to promoters associated with glucose metabolism [185]. Similar results have shown that Drosophila Nr4a (DHR38) is essential for carbohydrate metabolism, glycogen storage and ethanol metabolism [186,187]. Finally, animal models of insulin resistance and mismanaged glucose metabolism, such as ob/ob and $\mathrm{db} / \mathrm{db}$ mice or STZ treated or ZDF rats, demonstrate a significant decrease in Nr4a expression in muscle and adipose tissue [174]. These data demonstrate the intimate link between Nr4a transcriptional activity and glucose metabolism. In this section we will review the role of the Nr4a's in glucose metabolism across various tissues.

\subsubsection{Liver}

Given the connection between Nr4a's and glucose metabolism, the liver is an organ of immense interest. Full body Nr4a1 knock out mice present contradictory findings when comparing liver insulin sensitivity. Nr4a1 knock out mice fed a control diet had improved insulin sensitivity, while mice fed a high fat diet presented impaired insulin sensitivity, as demonstrated by hepatic glucose production rate and glucose infusion rate during euglycemic clamp studies [20]. Expression of the glycolytic genes Bpgm and Pgk1 was upregulated in the liver from high fat fed Nr4a1 knock out mice and expression of G6pc was downregulated, while expression of the gluconeogenic genes Fbp1 and Pgcla was upregulated. Interestingly, expression of the G6Pase, which allows glucose to be released from hepatocytes, was downregulated in Nr4a1 knock out hepatocytes under both feeding regimes [20]. It is important to note, however, that a recent study using Cre/flox mediated Nr4a1 deletion demonstrated that the previously published full body Nr4a1 knock out produces a N-terminal domain only truncated Nr4a1 that is sufficient to interact with and stabilize HIF1 $\alpha$ [52]. This report demonstrates that some of the phenotypes previously thought to be due to the genomic effects of Nr4a1 may in fact be due to non-genomic functions. Given this result, it is important to validate many of these findings using this model.

Primary hepatocytes treated with glucagon increase expression of Nr4a1, Nr4a2 and Nr4a3, in a cAMP dependent process [158]. Nr4a1 hepatic overexpression results in increased expression of Fbp1, Eno3, G6pc, Fbp2 and Glut 2 [158]. Similarly, Nr4a2 and Nr4a3 overexpression also induce expression of these target genes, resulting in increased gluconeogenesis. The Nr4a mediated induction of these genes correlates with direct binding of Nr4a1, Nr4a2 or Nr4a3 to NBRE sites in the target gene promoters [158].

A recent study demonstrated a direct connection between Nr4a1 and Gyk [188]. Gyk was shown to inhibit expression of two Nr4a1 liver target genes, Eno3 and ApoA5, demonstrating that increased 
levels of Gyk decreased expression of these targets through sequestering Nr4a1. This resulted in decreased Eno3, G6Pase and Fbp1 expression and ultimately decreased circulating blood glucose levels [188]. These results were validated with Gyk overexpression in the STZ treated mice and in $\mathrm{db} / \mathrm{db}$ mice. HepG2 Nr4a1 overexpression was sufficient to decrease expression of the gluconeogenic enzyme G6pc and PEPCK, while Nr4a1 knock down increased expression of these same target genes [161]. Treatment of mice with the conjugated linoleic acid (CLA) trans-10,cis-12-CLA resulted in increased expression of $\mathrm{Nr} 4 \mathrm{a} 1, \mathrm{Nr} 4 \mathrm{a} 2$ and $\mathrm{Nr} 4 \mathrm{a} 3$, as well as increased expression of the gluconeogenic genes G6pc, Eno3, PEPCK and PC [159]. Finally, treating mice with the Nr4a1 agonist Csn-B is sufficient to increase circulating blood glucose levels and induce expression of G6pc and Fbp1 [189]. Together these data demonstrate that Nr4a's (particularly Nr4a1) plays a critical role in regulating expression of glycolysis and gluconeogenesis in hepatocytes.

\subsubsection{Muscle}

The Nr4a family directly effects muscle glucose utilization pathways. Chao et al. demonstrated that $\mathrm{Nr} 4 \mathrm{a} 1$ is expressed in muscle in response to $\beta$-adrenergic signaling and that blocking this signal was sufficient to decrease expression of genes associated with glucose uptake (Glut4), glycolysis (Pfkm) and glycogenolysis (Pygm) [163]. Furthermore, Nr4a1 overexpression in C2C12 muscle cells or in electroporated primary muscle cells was sufficient to induce expression of these same gene classes. Finally, Nr4a1 knock out muscle demonstrated downregulation of these genes and luciferase and EMSA demonstrated Nr4a1 binding to the promoter of Glut4 and Eno3 [20]. Subsequent studies from the same group demonstrated that full body Nr4a1 knock out mice fed a high fat diet have impaired glucose tolerance and elevated circulating insulin levels [20]. Their data demonstrated muscular insulin resistance, decreased Glut4 expression, decreased insulin receptor phosphorylation and decreased expression of glycolytic genes such as Eno3, Bpgm and Pgk1. Further findings demonstrated that loss of Nr4a1 in muscle significantly impairs myofiber size and regeneration [166,167]. Nr4a1 overexpression or induction with metformin or the Nr4a1 pharmaceutical ligand DIM-C-pPhOH and its derivatives in C2C12 muscle cells increased expression of metabolic genes associated with glucose uptake, glycolysis and glycogenolysis, such as Glut4, PHKG1, PGAM2, Eno3, Aldo1 and Pygm [172]. This study demonstrated enhanced glucose uptake and showed that knock down of Nr4a1 impaired the induction observed with either metformin or DIM-C-pPhOH treatment [172]. Similarly, neonatal rat ventricular myocytes overexpressing Nr4a1 presented with elevated glycolysis, as well as induction of the hexosamine pathway branch through GFPT2 induction, resulting in enhanced O-GlcNAcylation of STIM1, ultimately affecting cardiac performance [171].

$\mathrm{Nr} 4 \mathrm{a} 3$ results in similar changes in glucose metabolism gene expression. Muscle specific Nr4a3 overexpression mice fed a control diet presented with decreased epididymal, inguinal, brown and total adipose mass [169]. This corresponded with significantly lower circulating leptin levels. When these mice were fed a high fat diet, the animals had decreased weight gain, adipose mass and circulating blood glucose [169]. Significant upregulation of glycolytic genes in the Nr4a3 overexpressing muscle was observed, including induction of HK1, Pfk-1, GAPDH, Pgam2, Eno3 and Pkm [169]. In addition, components of the malate aspartate shuttle, including MDH and AST, were upregulated, as was Pdh, with downregulation of the glycerol phosphate shuttle and decreased NAD+/NADH ratio, indicative of more efficient ATP production [169]. Nr4a3 overexpression in muscle also resulted in increased expression of the glycogenic genes Glut4, HK2, Stbd1 and Gys1, as well as downregulation of the glycogenolytic gene PPP1R1A [169]. This corresponded with increased muscular glycogen content [170]. Together, these data clearly demonstrate that Nr4a1 and Nr4a3 positively regulate glycolysis and glycogenesis within muscle cells.

\subsubsection{Adipose Tissue}

Nr4a's also play an important role in adipose tissue glucose utilization. The insulin sensitizing drugs pioglitazone and troglitazone increase adipose tissue glucose uptake and increase expression 
of Nr4a1 and Nr4a3 [174]. Similarly, insulin induces Nr4a expression in the 3T3-L1 adipocytes. Finally, overexpression or knock down of Nr4a3 is sufficient to impair adipocyte glucose uptake and overexpression of Nr4a3 causes increased Glut 4 expression and transport to the plasma membrane [174]. Interestingly, human adipose samples from obese subjects prior to bariatric surgery demonstrate significantly elevated expression of $\mathrm{Nr} 4 \mathrm{a} 1, \mathrm{Nr} 4 \mathrm{a} 2$ and $\mathrm{Nr} 4 \mathrm{a} 3$ and the expression level drops one year after surgery to levels observed in lean subjects [175]. These data support the hypothesis that Nr4a's control adipocyte glucose metabolism.

\subsection{4. $\beta$-cells}

Loss of Nr4a1 or Nr4a3 but not Nr4a2, in the 832/13 INS-1 $\beta$-cell line decreased expression of the glycolytic gene Eno1 [177]. No changes were observed, however, with Aldoa or Pgk1. Similar results are found in the MIN-6 cell line, where Nr4a1 expression was induced by culturing with palmitate, which increased Eno3 expression [179]. Nr4a1 is induced in $\beta$-cells in response to palmitate or oleate exposure [190]. Culturing INS-1 $\beta$-cells in the presence of oleate, followed by mass spectrometry to define changes to the $\beta$-cell proteome demonstrates downregulation of the glycolytic genes Eno1, Eno3, GAPDH and Pgk1 [178]. These data demonstrate that Nr4a1 and Nr4a3 are sufficient to regulate glycolytic gene expression in the pancreatic $\beta$-cell, which impinges on glucose utilization and insulin secretion.

\subsubsection{Immune System}

Changes in fuel metabolism are essential for immune cell differentiation and clonal expansion. A recent study of T-cell activation demonstrated that Nr4a1 knock out T-cells have greater rates of cellular proliferation [180]. This corresponds with increased basal respiration, maximal respiration, glycolysis and glycolytic capacity. They demonstrated upregulation of genes involved in glycolysis, including Hk2, Aldoa and Aldoc [180]. In addition to inducing glycolytic changes, changes were observed in glycogenesis (Gbe1) and glycogenolysis (Agl) [180]. A previous study demonstrated that loss of Nr4a1 impairs Treg differentiation, which corresponds with decreased glycolytic gene expression [191]. Interestingly, loss of Nr4a1 expression in macrophages impairs glycolysis in the LPS stimulated state [181]. This corresponds with decreased lactate production from anaerobic glycolysis. This shift to glycolytic metabolism during macrophage activation is essential for proper production of proinflammatory cytokines and nitric oxide, which is deregulated in $\mathrm{Nr} 4 \mathrm{a} 1 \mathrm{KO}$ mice, resulting in elevated atherosclerotic plaques. Finally, a floxed Nr4a1 mouse model demonstrated decreased expression of Glut1 and Pdk1 in bone marrow [52]. This model which gives complete Nr4a1 deletion, rather than production of the NTD domain only Nr4a1 emphasizes that Nr4a1 (rather than HIF1 $\alpha$ or another Nr4a1-NTD binding partner) regulates expression of glycolytic genes. Currently, however, these data suggest that Nr4a1 impedes glycolytic respiration in T-cells, a critical change during T-cell activation.

\subsubsection{Cancer}

Similar results are described in acute myeloid leukemia (AML) cells from patients and using the NB4 and THP1 cell lines. AML cells from patients have significantly decreased Nr4a1 expression as compared to healthy donors. siRNA mediated knockdown of Nr4a1 in the NB4 cell line caused increased proliferation, Glut1 and Ldha expression and lactate levels. These data suggest that in AML cells, loss of Nr4a1 results in enhanced glucose uptake and anaerobic glycolysis [182]. Treatment with dihydroergotamine (DHE) is sufficient to induce Nr4a1, Nr4a2 and Nr4a3 expression in AML cell lines. DHE treatment also results in induction of Eno3 expression [75]. Furthermore, ChIP-seq of Nr41 binding in AML cells demonstrates strong binding to promoters of various glycolytic genes, including Eno3 [47]. These data clearly demonstrate Nr4a1 regulating glycolytic gene expression in AML cells. 


\subsection{Lipid Metabolism}

Where glucose metabolism focuses on use and production of fuel in the fed state or short-term fuel storage in the form of glycogen, lipid metabolism focuses on the production and usage of the long-term fuel storage form. The Nr4a's play a role in liver, muscle and adipose tissue controlling the production and usage of lipids.

\subsubsection{Liver}

Nr4a1 full body knock outs have increased liver triglycerides, cholesterol and hepatic steatosis in response to high fat feeding [20]. This corresponds with increased even-chain acyl carnitine species, increased hepatic Lpl expression and decreased hepatic Ehhadh expression [20]. Hepatic adenoviral mediated Nr4a1 overexpression decreased circulating triglyceride levels, increased LDL levels and decreased HDL levels [160]. This correlates with significantly decreased expression of SREBP1c, FAS and Gpam. In addition, significant downregulation of lipid metabolism genes is observed with Nr4a1 overexpression [160]. Finally, Nr4a1 or Nr4a2 overexpression increased CPT1a in HEPG2 cells, permitting greater fatty acid mitochondrial translocation [162]. These data suggest that Nr4a1 and Nr4a2 push hepatocytes to greater fatty acid production and utilization.

\subsubsection{Muscle}

Nr4a1 knock down in C2C12 muscle cells decreases triglyceride hydrolysis, as measured by glycerol release [164]. This corresponds with decreased expression of the genes Glut4, CD36, AdipoR2, UCP2 and UCP3 [164]. Nr4a3 overexpression in muscle increased beta-oxidation. This corresponds with increased CRAT, ACSL, ACDH, ECH and 3-KCT expression, all needed for beta-oxidation [169,170]. Nr4a3 loss in $\mathrm{C} 2 \mathrm{C} 12$ cells impairs palmitate oxidation and increases anaerobic glycolysis [21]. This corresponded with decreased expression of PGC-1 $\alpha$, PGC-1 $\beta$, Lipin $1 \alpha$, Pdp1c and Pdp1r [21]. Conversely, treatment with the $\beta$-adrenergic activator formoterol enhances these genes associated with oxidative metabolism, presumably through Nr4a3 activation [21]. These data demonstrate that Nr4a1 and Nr4a3 are necessary for muscle lipid metabolism.

\subsubsection{Adipose Tissue}

The role of Nr4a's in adipocytes presents conflicting results. Loss of Nr4a1 in 3T3-L1 preadipocytes does not impair adipogenesis or lipid accumulation [192]. This is in contrast to a second report demonstrating that isoalantolactone, which inhibits Nr4a1 activity, decreases 3T3-L1 lipid accumulation [193] and subsequent studies demonstrating that Nr4a1 is essential for adipocyte progenitor function [194]. Finally, Nr4a1 induces p53 and GATA2 expression, which inhibits SREBP1c and PPAR $\gamma$ expression and impairs adipogenesis [173]. Therefore, the current data regarding Nr4a's and adipogenesis is conflicting.

\subsubsection{Cancer}

While most of the effects of Nr4a1 are directly linked to gene transcription, Nr4a1 does have non-genomic effects that can impinge on lipid metabolism. In melanoma, Nr4a1 translocates to the mitochondria and stabilize TP $\beta$ of the mitochondrial trifunctional protein through direct binding. This binding increasing TP $\beta$ activity and increase fatty acid oxidation [183]. Similarly, Nr4a2 induction induces fatty acid oxidation in colorectal cancer [184]. It does this by binding to the promoters and inducing expression of Acox, Cpt1m, Fabp2 and Fabp4.

\subsection{Mitochondrial Function}

Various studies have shown the direct link between Nr4a's and mitochondrial production and fuel oxidation. This encompasses transcriptional regulation of components of $\beta$-oxidation, TCA cycle 
and the ETC. This section focuses on the regulation controlled by the Nr4a's in various metabolically active tissues.

\subsubsection{Liver}

Loss of Nr4a1 impedes high fat diet mediated induction of non-alcoholic fatty liver disease [195]. This was shown to be due to a decrease in high fat diet mediated mitochondrial fission, oxidative stress and calcium overload [195]. These findings demonstrated decreased mitochondrial respiration in primary hepatocytes due to exposure to elevated levels of palmitate and through Nr4a1 upregulation.

\subsubsection{Muscle}

Nr4a1 overexpression in $\mathrm{C} 2 \mathrm{C} 12$ cells resulted in increased mitochondria number [167]. The increased expression of TCA and ETC components corresponds with enhanced glucose tolerance. Nr4a1 overexpression in muscle also resulted in increased levels of NADH-TR diaphorase, Cox1 and Sdhb, all of which result in increased mitochondrial activity [165]. In addition, these mice had greater mitochondrial DNA concentrations, suggesting increased mitogenesis. Muscle had increased Pdh phosphorylation, suggesting decreased pyruvate flux (and supported by elevated lactate levels). The muscle presented with increased fatty acid oxidation and a shift from mitochondrial pyruvate metabolism. The mice demonstrated increased muscle glycogen and increased glycogenesis. The Nr4a1 overexpressing animal muscle had greater mitochondrial respiration, increased expression of Complex 1 and ultimately increased muscle strength [165]. Similarly, C2C12 cells and primary muscle with Nr4a1 knock down demonstrated decreased Ucp3 expression [164]. Mice selected for running capacity have elevated Nr4a1 and Nr4a3 expression in soleus and EDL muscle [168]. Muscle samples from these mice had elevated expression of the Nr4a targets CD36 and Ucp3, as well as the ETC components Complex 1, Complex 2, Complex 3, Complex 4 and Complex 5. Nr4a3 overexpression in muscle increases TCA cycle flux. This corresponds with increased expression of Idh3, Ogdh, Scs, Sdhb, Fh and Mdh $[169,170]$. Increased levels of mitochondrial ETC components are also upregulated in muscle with Nr4a3 overexpression, including Atp5a1, Uqcr2, Cox1, Sdhb and Ndufb8 [170]. Together, the data is very clear that $\mathrm{Nr} 4 \mathrm{a} 1$ and $\mathrm{Nr} 4 \mathrm{a} 3$ are essential for muscle mitochondrial content and fuel oxidation.

\subsubsection{Adipose Tissue}

Using HIB-1B brown adipocytes and brown adipose tissue from warmth and cold exposed mice, it was shown that $\mathrm{Nr} 4 \mathrm{a} 1$ is induced in response to $\beta$-adrenergic signaling. Nr4a1 was shown to directly bind to the promoter of Ucp3 and induce its expression, thus defining a role for Nr4a1 as an effector of brown fat thermogenesis [176]. Further studies demonstrated that Nr4a3 also binds to the Ucp1 promoter and can induce its expression [178]. Together, these data demonstrate a connection between the Nr4a's, mitochondrial genesis and uncoupling in brown adipose tissue.

\subsection{4. $\beta$-Cells}

Loss of Nr4a1 or Nr4a3 but not Nr4a2, in 832/13 INS-1 $\beta$-cells results in impaired mitochondrial respiration [177]. Impaired mitochondrial respiration was observed with $\mathrm{Nr} 4 \mathrm{a} 1$ or $\mathrm{Nr} 4 \mathrm{a} 3$ deficiency but not Nr4a2 deficiency. Impaired respiration was observed in the Leak, OxPhos and ETS states. Measurements of mRNA and protein demonstrated significant decreases in the TCA and ETC components Idh3g and Sdhb. This resulted in decreased NADH and FADH2 cycling, decreased ATP levels and ultimately decreased glucose stimulated insulin secretion [177]. These data clearly demonstrate that $\mathrm{Nr} 4 \mathrm{a} 1$ and $\mathrm{Nr} 4 \mathrm{a} 3$ are essential for $\beta$-cell mitochondrial respiration.

\subsubsection{Immune System}

T-cell activation in the absence of Nr4a1 results in increased expression of the ETC components Atp5c1, Atp5f1, Atp5h, Cox6a1, Cox6b2, Cox7b, Ndufa6, Ndufa5, Ndufa8 and Ndufa11 [180]. 
There were also increased expression of the TCA components Dlst and Idh3a. These Nr4a1 deficient T cells had significantly greater basal and maximal respiration. Loss of Nr4a1 in macrophages impairs mitochondrial respiration in the presence or absence of LPS [181]. This corresponds with decreased mitochondrial numbers in the unstimulated state. Nr4a1 knock out macrophages have increased expression of Idh2, Idh3b and Idh3g in the stimulated state, corresponding with significantly elevated succinate levels. The increased succinate levels (and other TCA organic acids) provide added substrates for enhanced cytokine and nitric oxide production that results in enhanced atherosclerotic lesions [181] Woronicz, J.D.; Calnan, B.; Ngo, V.; Winoto, A. Requirement for the orphan steroid receptor Nur77 in apoptosis of T-cell hybridomas. Nature 1994, 367, 277-281, doi:10.1038/367277a0.

\section{Concluding Remarks}

The Nr4a family of orphan nuclear receptors play critical roles in cellular proliferation, apoptosis and fuel utilization. This occurs in a tissue specific mechanism, with a varied response depending on the tissue of interest. These data demonstrate a tissue specific ability of the Nr4a's to either enhance proliferation or induce apoptosis. These changes impinge on the energy status of the cell, specifically mitochondrial function. This connection to replication, survival and fuel utilization places the Nr4a's as a critical pharmaceutical target to treat various human disorders.

The mechanisms of Nr4a action are primarily through transcriptional induction or inhibition. The results acquired using the full body Nr4a1 knock out should be validated, however, using the floxed Nr4a1 knock out mice. As mentioned previously, this model results in complete Nr4a1 deletion, rather than expression of the NTD-Nr4a1 variant. These two models, used in tandem, will allow the genomic and non-genomic Nr4a1 functions to be independently defined.

It is interesting that Nr4a's play dual roles with the mitochondria. Nr4a's are essential for mitochondrial biogenesis and enzymatic components of the TCA cycle and electron transport chain, which impinge on fuel utilization. Conversely, Nr4a migration to the mitochondria has the ability to stabilize the mitochondria and inhibit the intrinsic apoptotic pathway. The connection between these two pathways warrants more study.

Future work needs to completely curate the Nr4a transcriptional targets through RNA-seq and ChIP-seq studies. Given the tissue specific differences, this is of high priority. Furthermore, while no endogenous ligands are yet defined, recent studies have begun to define putative endogenous ligands, as well as pharmaceutical agonists and antagonists. Greater exploration into the ability of these to modulate Nr4a function needs to be studies and their effects on various tissues. Finally, PTMs are known to modulate Nr4a family member activity. Greater definition of the types and locations of these PTMs, as well as their effect on proliferation, apoptosis and fuel utilization is needed.

Author Contributions: J.A.H., W.S.E. and J.S.T. each contributed to writing of the manuscript. All authors read and approved the final manuscript for publication.

Funding: This research was funded by the American Diabetes Association, grant number 1-17-IBS-101 (J.S.T.), by the Diabetes Action Research and Education Foundation, grant number 475 (J.S.T.), by the Beatson Foundation, grant number 2019-003 (J.S.T.) and by a BYU HBLL Student Research Grant (J.A.H.).

Acknowledgments: The authors thank the members of the Tessem lab for critical discussion regarding these topics.

Conflicts of Interest: The authors declare no conflict of interest.

\section{Abbreviations}

$\begin{array}{ll}\text { 3-KCT3 } & \text { ketoacyl-CoA thiolase } \\ 5-\mathrm{HT} & \text { 5-hydrovytryptamine } \\ \text { ACDH } & \text { Acyl-CoA dehydrogenase } \\ \text { Acox } & \text { acyl-CoA oxidase 1 } \\ \text { ACSL } & \text { Long-chain-fatty-acid-CoA ligase } \\ \text { Adcyap1 } & \text { Adenylate Cyclase Activating Polypeptide 1 } \\ \text { AdipoR2 } & \text { Adiponectin Receptor 2 }\end{array}$




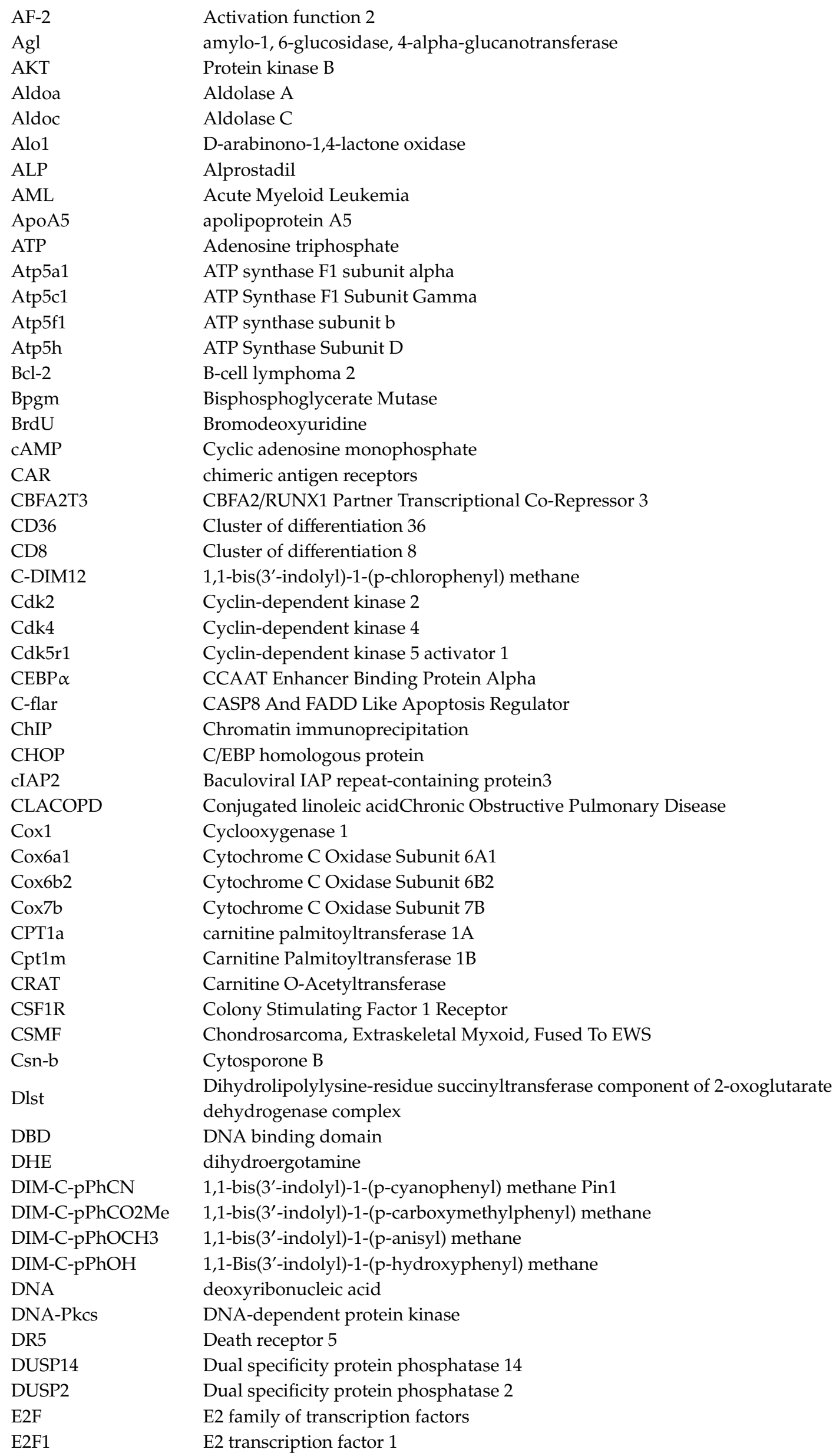




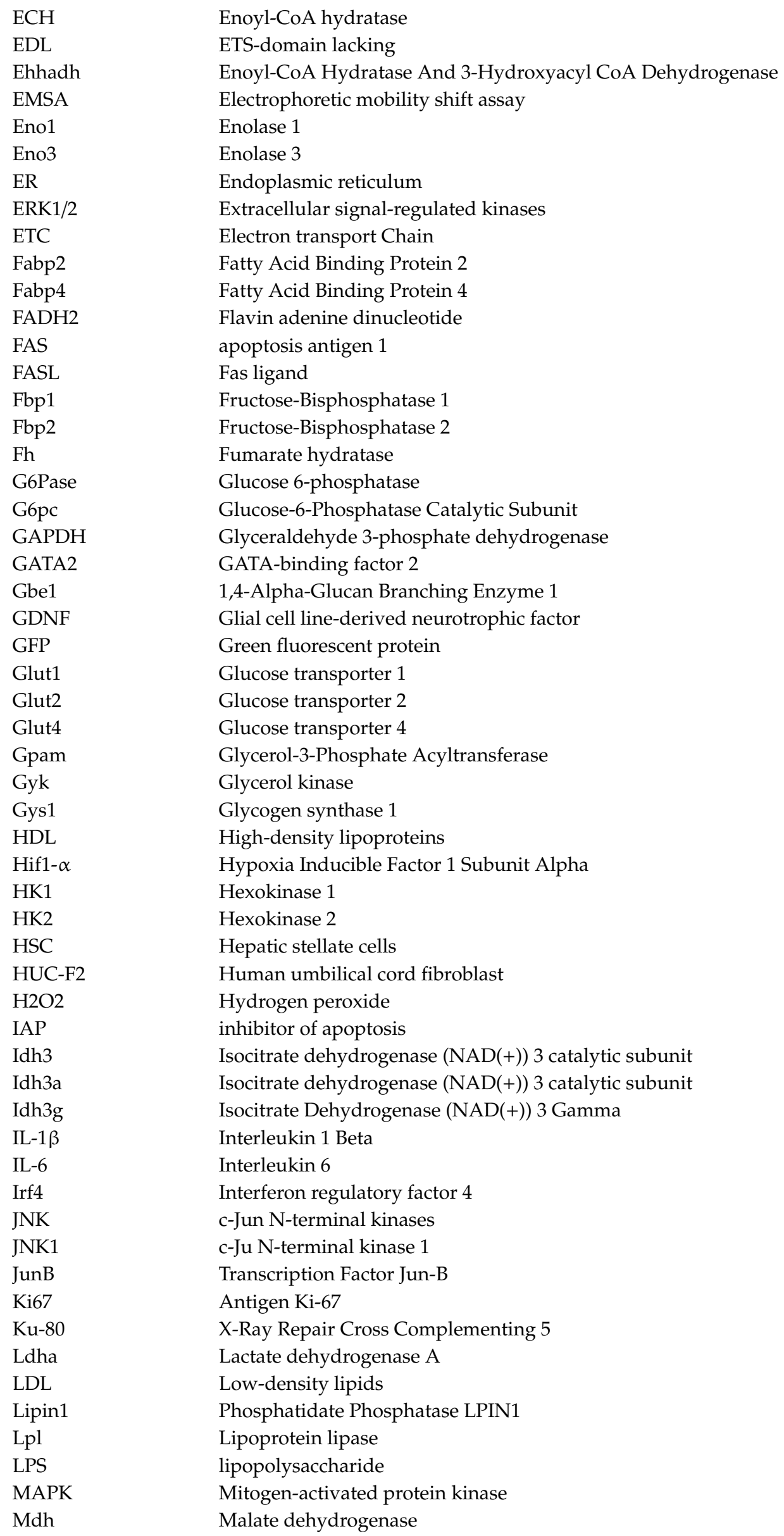




\begin{tabular}{|c|c|}
\hline MIN6 & Mouse Insulinoma 6 \\
\hline MINOR & Mitogen-Induced Nuclear Orphan Receptor \\
\hline mRNA & Messenger RNA \\
\hline MTT & (3-(4,5-dimethylthiazolyl-2)-2,5-diphenyltetrazolium bromide \\
\hline Мус & MYC Proto-Oncogene, BHLH Transcription Factor \\
\hline NAD+ & nicotinamide adenine dinucleotide \\
\hline $\mathrm{NADH}$ & nicotinamide adenine dinucleotide \\
\hline NADH-TR & nicotinamide adenine dinucleotide tetrazolium reductase \\
\hline NBRE & Nerve growth factor IB response element \\
\hline Ndufa11 & NADH:Ubiquinone Oxidoreductase Subunit A11 \\
\hline Ndufa5 & NADH:Ubiquinone Oxidoreductase Subunit A5 \\
\hline Ndufa6 & NADH:Ubiquinone Oxidoreductase Subunit A6 \\
\hline Ndufa8 & NADH:Ubiquinone Oxidoreductase Subunit A8 \\
\hline $\mathrm{NF}-\kappa \mathrm{B}$ & Nuclear factor kappa-light-chain-enhancer of activated B cells \\
\hline NGFI-B & Nuclear Receptor Subfamily 4 Group A Member 1 \\
\hline NOR1 & Nuclear Receptor Subfamily 4 Group A Member 3 \\
\hline NOT & Nuclear Receptor Subfamily 4 Group A Member 2 \\
\hline Nr4a1 & Nuclear Receptor Subfamily 4 Group A Member 1 \\
\hline $\mathrm{Nr} 4 \mathrm{a} 2$ & Nuclear Receptor Subfamily 4 Group A Member 2 \\
\hline $\mathrm{Nr} 4 \mathrm{a} 3$ & Nuclear Receptor Subfamily 4 Group A Member 3 \\
\hline NTD & N-Terminal Domain \\
\hline Nur77 & Nuclear Receptor Subfamily 4 Group A Member 1 \\
\hline NuRE & NGFIB Response Element-AAAGGTCA \\
\hline Nurr1 & Nuclear Receptor Subfamily 4 Group A Member 2 \\
\hline Ogdh & Oxoglutarate Dehydrogenase \\
\hline O-GlcNAcylation & O-Linked $\beta$-N-acetylglucosamineylation \\
\hline OxPhox & Oxidative Phosphorylation \\
\hline p21 & Cyclin-dependent kinase inhibitor 1 \\
\hline p27 & Cyclin-dependent kinase inhibitor $1 \mathrm{~B}$ \\
\hline p38 & Mitogen-Activated Protein Kinase 14 \\
\hline p53 & Tumor protein p53 \\
\hline PA & Palmitic acid \\
\hline PARP-1 & Poly(ADP-Ribose) Polymerase 1 \\
\hline PC & Pyruvate carboxylase \\
\hline PCNA & Proliferating cell nuclear antigen \\
\hline PDCD1 & Programmed Cell Death 1 \\
\hline PDGF & Platelet-derived growth factor \\
\hline Pdh & Pyruvate Dehydrogenase E1 Alpha 1 Subunit \\
\hline Pdk1 & Pyruvate Dehydrogenase Kinase 1 \\
\hline Pdp1c & Pyruvate Dehydrogenase Phosphatase Catalytic Subunit 2 \\
\hline Pdp1r & Pyruvate Dehydrogenase Phosphatase Catalytic Subunit 1 \\
\hline PEPCK & Phosphoenolpyruvate Carboxykinase \\
\hline Pfk-1 & Phosphofructokinase 1 \\
\hline Pim-1 & Proto-Oncogene, Serine/Threonine Kinase \\
\hline PKB & Protein kinase B \\
\hline PU.1 & Hematopoietic Transcription Factor PU.1 \\
\hline GADPH & Glyceraldehyde-3-Phosphate Dehydrogenase \\
\hline PGAM & Phosphoglycerate Mutase 2 \\
\hline PGC- $1 \alpha$ & PPARG Coactivator 1 Alpha \\
\hline PGC-1 $\beta$ & PPARG Coactivator 1 beta \\
\hline Pgc1a & PPARG Coactivator 1 Alpha \\
\hline Pgk1 & Phosphoglycerate Kinase 1 \\
\hline PHKG1 & Phosphorylase Kinase Catalytic Subunit Gamma 1 \\
\hline Pin1 & Peptidylprolyl Cis/Trans Isomerase, NIMA-Interacting 1 \\
\hline Pkm & Pyruvate Kinase M1/2 \\
\hline $\operatorname{PPAR} \gamma$ & Peroxisome Proliferator Activated Receptor Gamma \\
\hline PPP1R1A & Protein Phosphatase 1 Regulatory Inhibitor Subunit 1A \\
\hline
\end{tabular}




\begin{tabular}{|c|c|}
\hline $\mathrm{pRB}$ & Retinoblastoma protein \\
\hline PTM & Post-translational modifications \\
\hline PTMs & Post-translational modifications \\
\hline pVHL & von Hippel-Lindau tumor suppressor \\
\hline Pygm & Glycogen Phosphorylase, Muscle Associated \\
\hline RNA & Ribonucleic acid \\
\hline ROS & Reactive oxygen species \\
\hline RUNX1 & Runt-related transcription factor 1 \\
\hline Scs & Succinate-CoA Ligase ADP-Forming Beta Subunit \\
\hline Sdhb & Succinate Dehydrogenase Complex Iron Sulfur Subunit B \\
\hline shRNA & small hairpin RNA \\
\hline siRNA & small interfering RNA \\
\hline SMAD3 & Mothers against decapentaplegic homolog 3 \\
\hline SOD1 & Superoxide dismutase \\
\hline SREBP1c & Sterol Regulatory Element Binding Transcription Factor 1 \\
\hline STAT3 & Signal transducer and activator of transcription 3 \\
\hline Stbd1 & Starch Binding Domain 1 \\
\hline STZ & streptozotocin \\
\hline TCA & Tricarboxylic acid cycle \\
\hline TG & Thapsigargin \\
\hline TGF- $\beta 1$ & Transforming growth factor beta- 1 \\
\hline TGF $\beta 3$ & Transforming growth factor beta-3 \\
\hline TINUR & Transcriptionally-Inducible Nuclear Receptor \\
\hline TNF & Tumor Necrosis Factor \\
\hline $\mathrm{TP} \beta$ & Hydroxyacyl-CoA Dehydrogenase Trifunctional Multienzyme Complex Subunit Beta \\
\hline TRAIL & TNF-related apoptosis-inducing ligand \\
\hline $\mathrm{TRAP} \gamma$ & TRAP-Complex Gamma Subunit \\
\hline Treg & Regulatory T Cell \\
\hline TUNEL & Terminal deoxynucleotidyl transferase-mediated dUTP nick-end labeling \\
\hline TXNDC5 & Thioredoxin Domain-Containing Protein 5 \\
\hline Ube2c & Ubiquitin-conjugating enzyme E2 C \\
\hline Ucp1 & Uncoupling Protein 1 \\
\hline $\mathrm{UCP} 2$ & Uncoupling Protein 2 \\
\hline UCP3 & Uncoupling Protein 3 \\
\hline Uqcr2 & Ubiquinol-Cytochrome C Reductase Core Protein 2 \\
\hline VCAM1 & Vascular cell adhesion protein 1 \\
\hline VEGF & Vascular endothelial growth factor \\
\hline VEGF-A & Vascular endothelial growth factor A \\
\hline VSMC & Vascular smooth muscle cell \\
\hline WT1 & Wilms tumor \\
\hline
\end{tabular}

\section{References}

1. Okabe, T.; Takayanagi, R.; Imasaki, K.; Haji, M.; Nawata, H.; Watanabe, T. cDNA cloning of a NGFI-B/ nur77-related transcription factor from an apoptotic human T cell line. J. Immunol. 1995, 154, 3871-3879.

2. Saucedo-Cardenas, O.; Kardon, R.; Ediger, T.R.; Lydon, J.P.; Conneely, O.M. Cloning and structural organization of the gene encoding the murine nuclear receptor transcription factor, NURR1. Gene 1997, 187, 135-139. [CrossRef]

3. Zhang, L.; Wang, Q.; Liu, W.; Liu, F.; Ji, A.; Li, Y. The Orphan Nuclear Receptor 4A1: A Potential New Therapeutic Target for Metabolic Diseases. J. Diabetes Res. 2018, 2018, 9363461. [CrossRef] [PubMed]

4. de Vera, I.M.; Giri, P.K.; Munoz-Tello, P.; Brust, R.; Fuhrmann, J.; Matta-Camacho, E.; Shang, J.; Campbell, S.; Wilson, H.D.; Granados, J.; et al. Identification of a Binding Site for Unsaturated Fatty Acids in the Orphan Nuclear Receptor Nurr1. Acs Chem. Biol. 2016, 11, 1795-1799. [CrossRef] [PubMed] 
5. de Vera, I.M.S.; Munoz-Tello, P.; Zheng, J.; Dharmarajan, V.; Marciano, D.P.; Matta-Camacho, E.; Giri, P.K.; Shang, J.; Hughes, T.S.; Rance, M.; et al. Defining a Canonical Ligand-Binding Pocket in the Orphan Nuclear Receptor Nurr1. Structure 2019, 27, 66.e65-77.e65. [CrossRef]

6. Vinayavekhin, N.; Saghatelian, A. Discovery of a protein-metabolite interaction between unsaturated fatty acids and the nuclear receptor Nur77 using a metabolomics approach. J. Am. Chem. Soc. 2011, 133, 17168-17171. [CrossRef]

7. Wilson, T.E.; Fahrner, T.J.; Johnston, M.; Milbrandt, J. Identification of the DNA binding site for NGFI-B by genetic selection in yeast. Science 1991, 252, 1296-1300. [CrossRef]

8. Wilson, T.E.; Fahrner, T.J.; Milbrandt, J. The orphan receptors NGFI-B and steroidogenic factor 1 establish monomer binding as a third paradigm of nuclear receptor-DNA interaction. Mol. Cell Biol. 1993, 13, 5794-5804. [CrossRef]

9. Maira, M.; Martens, C.; Philips, A.; Drouin, J. Heterodimerization between members of the Nur subfamily of orphan nuclear receptors as a novel mechanism for gene activation. Mol. Cell Biol. 1999, 19, 7549-7557. [CrossRef]

10. Close, A.F.; Rouillard, C.; Buteau, J. NR4A orphan nuclear receptors in glucose homeostasis: A minireview. Diabetes Metab. 2013, 39, 478-484. [CrossRef]

11. Gissendanner, C.R.; Kelley, K.; Nguyen, T.Q.; Hoener, M.C.; Sluder, A.E.; Maina, C.V. The Caenorhabditis elegans NR4A nuclear receptor is required for spermatheca morphogenesis. Dev. Biol. 2008, 313, 767-786. [CrossRef] [PubMed]

12. Forman, B.M.; Umesono, K.; Chen, J.; Evans, R.M. Unique response pathways are established by allosteric interactions among nuclear hormone receptors. Cell 1995, 81, 541-550. [CrossRef]

13. Pearen, M.A.; Muscat, G.E. Minireview: Nuclear hormone receptor 4A signaling: Implications for metabolic disease. Mol. Endocrinol. 2010, 24, 1891-1903. [CrossRef] [PubMed]

14. Milbrandt, J. Nerve growth factor induces a gene homologous to the glucocorticoid receptor gene. Neuron 1988, 1, 183-188. [CrossRef]

15. Law, S.W.; Conneely, O.M.; DeMayo, F.J.; O'Malley, B.W. Identification of a new brain-specific transcription factor, NURR1. Mol. Endocrinol. 1992, 6, 2129-2135. [CrossRef]

16. Ohkura, N.; Ito, M.; Tsukada, T.; Sasaki, K.; Yamaguchi, K.; Miki, K. Structure, mapping and expression of a human NOR-1 gene, the third member of the Nur77/NGFI-B family. Biochim. Biophys. Acta. 1996, 1308, 205-214. [CrossRef]

17. Bookout, A.L.; Jeong, Y.; Downes, M.; Yu, R.T.; Evans, R.M.; Mangelsdorf, D.J. Anatomical profiling of nuclear receptor expression reveals a hierarchical transcriptional network. Cell 2006, 126, 789-799. [CrossRef]

18. Mullican, S.E.; Zhang, S.; Konopleva, M.; Ruvolo, V.; Andreeff, M.; Milbrandt, J.; Conneely, O.M. Abrogation of nuclear receptors Nr4a3 and Nr4a1 leads to development of acute myeloid leukemia. Nat. Med. 2007, 13, 730-735. [CrossRef]

19. Chao, L.C.; Bensinger, S.J.; Villanueva, C.J.; Wroblewski, K.; Tontonoz, P. Inhibition of adipocyte differentiation by Nur77, Nurr1 and Nor1. Mol. Endocrinol. 2008, 22, 2596-2608. [CrossRef]

20. Chao, L.C.; Wroblewski, K.; Zhang, Z.; Pei, L.; Vergnes, L.; Ilkayeva, O.R.; Ding, S.Y.; Reue, K.; Watt, M.J.; Newgard, C.B.; et al. Insulin resistance and altered systemic glucose metabolism in mice lacking Nur77. Diabetes 2009, 58, 2788-2796. [CrossRef]

21. Pearen, M.A.; Myers, S.A.; Raichur, S.; Ryall, J.G.; Lynch, G.S.; Muscat, G.E. The orphan nuclear receptor, NOR-1, a target of beta-adrenergic signaling, regulates gene expression that controls oxidative metabolism in skeletal muscle. Endocrinology 2008, 149, 2853-2865. [CrossRef] [PubMed]

22. Tessem, J.S.; Moss, L.G.; Chao, L.C.; Arlotto, M.; Lu, D.; Jensen, M.V.; Stephens, S.B.; Tontonoz, P.; Hohmeier, H.E.; Newgard, C.B. Nkx6.1 regulates islet beta-cell proliferation via Nr4a1 and Nr4a3 nuclear receptors. Proc. Natl. Acad. Sci. USA 2014, 111, 5242-5247. [CrossRef] [PubMed]

23. Myers, S.A.; Eriksson, N.; Burow, R.; Wang, S.C.; Muscat, G.E. Beta-adrenergic signaling regulates NR4A nuclear receptor and metabolic gene expression in multiple tissues. Mol. Cell Endocrinol. 2009, 309, 101-108. [CrossRef] [PubMed]

24. Maxwell, M.A.; Muscat, G.E. The NR4A subgroup: Immediate early response genes with pleiotropic physiological roles. Nucl. Recept. Signal 2006, 4, e002. [CrossRef]

25. Pawlak, A.; Strzadala, L.; Kalas, W. Non-genomic effects of the NR4A1/Nur77/TR3/NGFIB orphan nuclear receptor. Steroids 2015, 95, 1-6. [CrossRef] 
26. Hu, Y.; Zhan, Q.; Liu, H.-X.; Chau, T.; Li, Y.; Yvonne Wan, Y.-J. Accelerated Partial Hepatectomy-Induced Liver Cell Proliferation Is Associated with Liver Injury in Nur77 Knockout Mice. Am. J. Pathol. 2014, 184, 3272-3283. [CrossRef]

27. Liu, Y.; Zhang, J.; Yi, B.; Chen, M.; Qi, J.; Yin, Y.; Lu, X.; Jasmin, J.-F.; Sun, J. Nur77 Suppresses Pulmonary Artery Smooth Muscle Cell Proliferation Through Inhibition of the STAT3/Pim-1/NFAT Pathway. Am. J. Respir. Cell Mol. Biol. 2013, 50. [CrossRef]

28. Chen, P.; Li, J.; Huo, Y.; Lu, J.; Wan, L.; Li, B.; Gan, R.; Guo, C. Orphan nuclear receptor NR4A2 inhibits hepatic stellate cell proliferation through MAPK pathway in liver fibrosis. PeerJ 2015, 3, e1518. [CrossRef]

29. Chen, P.; Li, J.; Huo, Y.; Lu, J.; Wan, L.; Yang, Q.; Huang, J.; Gan, R.; Guo, C. Adenovirus-mediated expression of orphan nuclear receptor NR4A2 targeting hepatic stellate cell attenuates liver fibrosis in rats. Sci. Rep. 2016, 6. [CrossRef]

30. de Waard, V.; Arkenbout, E.K.; Vos, M.; Mocking, A.I.; Niessen, H.W.; Stooker, W.; de Mol, B.A.; Quax, P.H.; Bakker, E.N.; VanBavel, E.; et al. TR3 nuclear orphan receptor prevents cyclic stretch-induced proliferation of venous smooth muscle cells. Am. J. Pathol. 2006, 168, 2027-2035. [CrossRef]

31. Arkenbout, E.K.; de Waard, V.; van Bragt, M.; van Achterberg, T.A.; Grimbergen, J.M.; Pichon, B.; Pannekoek, H.; de Vries, C.J. Protective function of transcription factor TR3 orphan receptor in atherogenesis: Decreased lesion formation in carotid artery ligation model in TR3 transgenic mice. Circulation 2002, 106, 1530-1535. [CrossRef] [PubMed]

32. Bonta, P.I.; Pols, T.W.H.; van Tiel, C.M.; Vos, M.; Arkenbout, E.K.; Rohlena, J.; Koch, K.T.; de Maat, M.P.M.; Tanck, M.W.T.; de Winter, R.J.; et al. Nuclear Receptor Nurr1 Is Expressed In and Is Associated With Human Restenosis and Inhibits Vascular Lesion Formation In Mice Involving Inhibition of Smooth Muscle Cell Proliferation and Inflammation. Circulation 2010, 121, 2023-2032. [CrossRef] [PubMed]

33. Nomiyama, T.; Nakamachi, T.; Gizard, F.; Heywood, E.B.; Jones, K.L.; Ohkura, N.; Kawamori, R.; Conneely, O.M.; Bruemmer, D. The NR4A Orphan Nuclear Receptor NOR1 Is Induced by Platelet-derived Growth Factor and Mediates Vascular Smooth Muscle Cell Proliferation. J. Biol. Chem. 2006, 281, 33467-33476. [CrossRef] [PubMed]

34. Wang, C.-G.; Lei, W.; Li, C.; Zeng, D.-X.; Huang, J.-A. Neuron-derived orphan receptor 1 promoted human pulmonary artery smooth muscle cells proliferation. Exp. Lung Res. 2015, 41, 208-215. [CrossRef] [PubMed]

35. Draney, C.; Hobson, A.E.; Grover, S.G.; Jack, B.O.; Tessem, J.S. Cdk5r1 Overexpression Induces Primary beta-Cell Proliferation. J. Diabetes Res. 2016, 2016, 6375804. [CrossRef] [PubMed]

36. Nowyhed, H.N.; Huynh, T.R.; Thomas, G.D.; Blatchley, A.; Hedrick, C.C. Cutting Edge: The Orphan Nuclear Receptor Nr4a1 Regulates CD8+ T Cell Expansion and Effector Function through Direct Repression of Irf4. J. Immunol. 2015, 195, 3515-3519. [CrossRef]

37. Tel-Karthaus, N.; Kers-Rebel, E.D.; Looman, M.W.; Ichinose, H.; de Vries, C.J.; Ansems, M. Nuclear Receptor Nur77 Deficiency Alters Dendritic Cell Function. Front. Immunol. 2018, 9. [CrossRef]

38. Ashraf, S.; Hegazy, Y.K.; Harmancey, R. Nuclear receptor subfamily 4 group A member 2 inhibits activation of ERK signaling and cell growth in response to $\beta$-adrenergic stimulation in adult rat cardiomyocytes. Am. J. Physiol. Cell Physiol. 2019, 317, C513-C524. [CrossRef]

39. Qing, H.; Liu, Y.; Zhao, Y.; Aono, J.; Jones, K.L.; Heywood, E.B.; Howatt, D.; Binkley, C.M.; Daugherty, A.; Liang, Y.; et al. Deficiency of the NR4A Orphan Nuclear Receptor NOR1 in Hematopoietic Stem Cells Accelerates Atherosclerosis. Stem Cells 2014, 32, 2419-2429. [CrossRef]

40. Freire, P.R.; Conneely, O.M. NR4A1 and NR4A3 restrict HSC proliferation via reciprocal regulation of C/EBPalpha and inflammatory signaling. Blood 2018, 131, 1081-1093. [CrossRef]

41. Duren, R.P.; Boudreaux, S.P.; Conneely, O.M. Genome Wide Mapping of NR4A Binding Reveals Cooperativity with ETS Factors to Promote Epigenetic Activation of Distal Enhancers in Acute Myeloid Leukemia Cells. PLoS ONE 2016, 11, e0150450. [CrossRef] [PubMed]

42. Boudreaux, S.P.; Ramirez-Herrick, A.M.; Duren, R.P.; Conneely, O.M. Genome-wide profiling reveals transcriptional repression of MYC as a core component of NR4A tumor suppression in acute myeloid leukemia. Oncogenesis 2012, 1, e19. [CrossRef] [PubMed]

43. Yin, H.; Lo, J.H.; Kim, J.-Y.; Marsh, E.E.; Kim, J.J.; Ghosh, A.K.; Bulun, S.; Chakravarti, D. Expression Profiling of Nuclear Receptors Identifies Key Roles of NR4A Subfamily in Uterine Fibroids. Mol. Endocrinol. 2013, 27, 726-740. [CrossRef] 
44. Hedrick, E.; Lee, S.-O.; Kim, G.; Abdelrahim, M.; Jin, U.-H.; Safe, S.; Abudayyeh, A. Nuclear Receptor 4A1 (NR4A1) as a Drug Target for Renal Cell Adenocarcinoma. PLoS ONE 2015, 10, e0128308. [CrossRef]

45. Deutsch, A.J.A.; Rinner, B.; Pichler, M.; Prochazka, K.; Pansy, K.; Bischof, M.; Fechter, K.; Hatzl, S.; Feichtinger, J.; Wenzl, K.; et al. NR4A3 Suppresses Lymphomagenesis through Induction of Proapoptotic Genes. Cancer Res. 2017, 77, 2375-2386. [CrossRef]

46. Zhang, L.; Liu, W.; Wang, Q.; Li, Q.; Wang, H.; Wang, J.; Teng, T.; Chen, M.; Ji, A.; Li, Y. New Drug Candidate Targeting the 4A1 Orphan Nuclear Receptor for Medullary Thyroid Cancer Therapy. Molecules 2018, 565. [CrossRef]

47. Ji, L.; Gong, C.; Ge, L.; Song, L.; Chen, F.; Jin, C.; Zhu, H.; Zhou, G. Orphan nuclear receptor Nurr1 as a potential novel marker for progression in human pancreatic ductal adenocarcinoma. Exp. Ther. Med. 2016, 13, 551-559. [CrossRef]

48. Zhu, B.; Sun, L.; Luo, W.; Li, M.; Coy, D.H.; Yu, L.; Yu, W. Activated Notch signaling augments cell growth in hepatocellular carcinoma via up-regulating the nuclear receptor NR4A2. Oncotarget 2017, 8. [CrossRef]

49. Llopis, S.; Singleton, B.; Duplessis, T.; Carrier, L.; Rowan, B.; Williams, C. Dichotomous roles for the orphan nuclear receptor NURR1 in breast cancer. BMC Cancer 2013, 13. [CrossRef]

50. Zhao, D.; Desai, S.; Zeng, H. VEGF stimulates PKD-mediated CREB-dependent orphan nuclear receptor Nurr1 expression: Role in VEGF-induced angiogenesis. Int. J. Cancer 2010, 128, 2602-2612. [CrossRef]

51. Eger, G.; Papadopoulos, N.; Lennartsson, J.; Heldin, C.-H. NR4A1 Promotes PDGF-BB-Induced Cell Colony Formation in Soft Agar. PLoS ONE 2014, 9, e109047. [CrossRef] [PubMed]

52. Vacca, M.; Murzilli, S.; Salvatore, L.; Di Tullio, G.; D’Orazio, A.; Lo Sasso, G.; Graziano, G.; Pinzani, M.; Chieppa, M.; Mariani-Costantini, R.; et al. Neuron-Derived Orphan Receptor 1 Promotes Proliferation of Quiescent Hepatocytes. Gastroenterology 2013, 144, 1518-1529. [CrossRef] [PubMed]

53. Yu, Y.; Cai, Z.; Cui, M.; Nie, P.; Sun, Z.H.E.; Sun, S.; Chu, S.; Wang, X.; Hu, L.; Yi, J.; et al. The orphan nuclear receptor Nur77 inhibits low shear stress-induced carotid artery remodeling in mice. Int. J. Mol. Med. 2015, 36, 1547-1555. [CrossRef] [PubMed]

54. Wang, C.-g.; Li, C.; Lei, W.; Jiang, J.-H.; Huang, J.-a.; Zeng, D.-x. The association of neuron-derived orphan receptor 1 with pulmonary vascular remodeling in COPD patients. Int. J. Chronic Obstr. Pulm. Dis. 2018, 13, 1177-1186. [CrossRef] [PubMed]

55. Li, X.; Tai, H.H. Activation of thromboxane A2 receptors induces orphan nuclear receptor Nurr1 expression and stimulates cell proliferation in human lung cancer cells. Carcinogenesis 2009, 30, 1606-1613. [CrossRef]

56. Chen, H.Z.; Li, L.; Wang, W.J.; Du, X.D.; Wen, Q.; He, J.P.; Zhao, B.X.; Li, G.D.; Zhou, W.; Xia, Y.; et al. Prolyl isomerase Pin1 stabilizes and activates orphan nuclear receptor TR3 to promote mitogenesis. Oncogene 2011, 31, 2876-2887. [CrossRef]

57. Wu, H.; Bi, J.; Peng, Y.; Huo, L.; Yu, X.; Yang, Z.; Zhou, Y.; Qin, L.; Xu, Y.; Liao, L.; et al. Nuclear receptor NR4A1 is a tumor suppressor down-regulated in triple-negative breast cancer. Oncotarget 2017, 8. [CrossRef]

58. Zeng, H.; Qin, L.; Zhao, D.; Tan, X.; Manseau, E.J.; Van Hoang, M.; Senger, D.R.; Brown, L.F.; Nagy, J.A.; Dvorak, H.F. Orphan nuclear receptor TR3/Nur77 regulates VEGF-A-induced angiogenesis through its transcriptional activity. J. Exp. Med. 2006, 203, 719-729. [CrossRef]

59. Zu, G.; Yao, J.; Ji, A.; Ning, S.; Luo, F.; Li, Z.; Feng, D.; Rui, Y.; Li, Y.; Wang, G.; et al. Nurr1 promotes intestinal regeneration after ischemia/reperfusion injury by inhibiting the expression of p21 (Waf1/Cip1). J. Mol. Med. 2016, 95, 83-95. [CrossRef]

60. Koenis, D.S.; Medzikovic, L.; Vos, M.; Beldman, T.J.; van Loenen, P.B.; van Tiel, C.M.; Hamers, A.A.J.; Otermin Rubio, I.; de Waard, V.; de Vries, C.J.M. Nur77 variants solely comprising the amino-terminal domain activate hypoxia-inducible factor-1alpha and affect bone marrow homeostasis in mice and humans. J. Biol. Chem. 2018, 293, 15070-15083. [CrossRef]

61. Xiang, T.; Zhang, S.; Cheng, N.; Ge, S.; Wen, J.; Xiao, J.; Wu, X. Oxidored-nitro domain-containing protein 1 promotes liver fibrosis by activating the Wnt/ $\beta$-catenin signaling pathway in vitro. Mol. Med. Rep. 2017, 16, 5050-5054. [CrossRef] [PubMed]

62. Medzikovic, L.; van Roomen, C.; Baartscheer, A.; van Loenen, P.B.; de Vos, J.; Bakker, E.; Koenis, D.S.; Damanafshan, A.; Creemers, E.E.; Arkenbout, E.K.; et al. Nur77 protects against adverse cardiac remodelling by limiting neuropeptide $\mathrm{Y}$ signalling in the sympathoadrenal-cardiac axis. Cardiovasc. Res. 2018, 114, 1617-1628. [CrossRef] [PubMed] 
63. Sekiya, T.; Kashiwagi, I.; Yoshida, R.; Fukaya, T.; Morita, R.; Kimura, A.; Ichinose, H.; Metzger, D.; Chambon, P.; Yoshimura, A. Nr4a receptors are essential for thymic regulatory T cell development and immune homeostasis. Nat. Immunol. 2013, 14, 230-237. [CrossRef] [PubMed]

64. Prince, L.R.; Prosseda, S.D.; Higgins, K.; Carlring, J.; Prestwich, E.C.; Ogryzko, N.V.; Rahman, A.; Basran, A.; Falciani, F.; Taylor, P.; et al. NR4A orphan nuclear receptor family members, NR4A2 and NR4A3, regulate neutrophil number and survival. Blood 2017, 130, 1014-1025. [CrossRef]

65. Nagaoka, M.; Yashiro, T.; Uchida, Y.; Ando, T.; Hara, M.; Arai, H.; Ogawa, H.; Okumura, K.; Kasakura, K.; Nishiyama, C. The Orphan Nuclear Receptor NR4A3 Is Involved in the Function of Dendritic Cells. J. Immunol. 2017, 199, 2958-2967. [CrossRef]

66. Kolluri, S.K.; Bruey-Sedano, N.; Cao, X.; Lin, B.; Lin, F.; Han, Y.H.; Dawson, M.I.; Zhang, X.k. Mitogenic Effect of Orphan Receptor TR3 and Its Regulation by MEKK1 in Lung Cancer Cells. Mol. Cell. Biol. 2003, 23, 8651-8667. [CrossRef]

67. Zhu, B.; Yang, J.-R.; Jia, Y.; Zhang, P.; Shen, L.; Li, X.-L.; Li, J.; Wang, B. Overexpression of NR4A1 is associated with tumor recurrence and poor survival in non-small-cell lung carcinoma. Oncotarget 2017, 8. [CrossRef]

68. Zhang, M.; Wu, J.; Zhong, W.; Zhao, Z.; Liu, Z. Long non-coding RNA BRE-AS1 represses non-small cell lung cancer cell growth and survival via up-regulating NR4A3. Arch. Biochem. Biophys. 2018, 660, 53-63. [CrossRef]

69. Xie, X.; Lin, J.; Liu, J.; Huang, M.; Zhong, Y.; Liang, B.; Song, X.; Gu, S.; Chang, X.; Huang, D.; et al. A novel lncRNA NR4A1AS up-regulates orphan nuclear receptor NR4A1 expression by blocking UPF1-mediated mRNA destabilization in colorectal cancer. Clin. Sci. 2019, 133, 1457-1473. [CrossRef]

70. Huang, M.; Xie, X.; Song, X.; Gu, S.; Chang, X.; Su, T.; Liang, B.; Huang, D. MiR-506 Suppresses Colorectal Cancer Development by Inhibiting Orphan Nuclear Receptor NR4A1 Expression. J. Cancer 2019, 10, 3560-3570. [CrossRef]

71. Wu, H.; Lin, Y.; Li, W.; Sun, Z.; Gao, W.; Zhang, H.; Xie, L.; Jiang, F.; Qin, B.; Yan, T.; et al. Regulation of Nur77 expression by $\beta$-catenin and its mitogenic effect in colon cancer cells. Faseb. J. 2011, 25, 192-205. [CrossRef] [PubMed]

72. Cho, S.D.; Yoon, K.; Chintharlapalli, S.; Abdelrahim, M.; Lei, P.; Hamilton, S.; Khan, S.; Ramaiah, S.K.; Safe, S. Nur77 Agonists Induce Proapoptotic Genes and Responses in Colon Cancer Cells through Nuclear Receptor-Dependent and Nuclear Receptor-Independent Pathways. Cancer Res. 2007, 67, 674-683. [CrossRef] [PubMed]

73. Tenga, A.; Beard, J.A.; Takwi, A.; Wang, Y.-M.; Chen, T. Regulation of Nuclear Receptor Nur77 by miR-124. PLoS One 2016, 11, e0148433. [CrossRef] [PubMed]

74. Lee, S.O.; Abdelrahim, M.; Yoon, K.; Chintharlapalli, S.; Papineni, S.; Kim, K.; Wang, H.; Safe, S. Inactivation of the orphan nuclear receptor TR3/Nur77 inhibits pancreatic cancer cell and tumor growth. Cancer Res. 2010, 70, 6824-6836. [CrossRef]

75. Ouyang, J.U.E.; Wu, M.; Huang, C.; Cao, L.I.; Li, G. Overexpression of oxidored-nitro domain containing protein 1 inhibits human nasopharyngeal carcinoma and cervical cancer cell proliferation and induces apoptosis: Involvement of mitochondrial apoptotic pathways. Oncol. Rep. 2012, 29, 79-86. [CrossRef]

76. Sun, L.; Liu, M.; Sun, G.-C.; Yang, X.; Qian, Q.; Feng, S.; Mackey, L.V.; Coy, D.H. Notch Signaling Activation in Cervical Cancer Cells Induces Cell Growth Arrest with the Involvement of the Nuclear Receptor NR4A2. J. Cancer 2016, 7, 1388-1395. [CrossRef]

77. Haller, F.; Bieg, M.; Will, R.; Körner, C.; Weichenhan, D.; Bott, A.; Ishaque, N.; Lutsik, P.; Moskalev, E.A.; Mueller, S.K.; et al. Enhancer hijacking activates oncogenic transcription factor NR4A3 in acinic cell carcinomas of the salivary glands. Nat. Commun. 2019, 10. [CrossRef]

78. Ramirez-Herrick, A.M.; Mullican, S.E.; Sheehan, A.M.; Conneely, O.M. Reduced NR4A gene dosage leads to mixed myelodysplastic/myeloproliferative neoplasms in mice. Blood 2011, 117, 2681-2690. [CrossRef]

79. Boudreaux, S.P.; Duren, R.P.; Call, S.G.; Nguyen, L.; Freire, P.R.; Narayanan, P.; Redell, M.S.; Conneely, O.M. Drug targeting of NR4A nuclear receptors for treatment of acute myeloid leukemia. Leukemia 2019, 33, 52-63. [CrossRef]

80. Mizushima, T.; Tirador, K.A.; Miyamoto, H. Androgen receptor activation: A prospective therapeutic target for bladder cancer? Expert Opin. Ther. Targets 2017, 21, 249-257. [CrossRef] 
81. Sun, L.; Zhou, R.; Dong, J.; Liu, S.; Jiao, Y.; Wang, L.; Hu, S.; He, P.; Liu, X.; Zhao, X.; et al. Lnc-NA inhibits proliferation and metastasis in endometrioid endometrial carcinoma through regulation of NR4A1. J. Cell. Mol. Med. 2019. [CrossRef] [PubMed]

82. Hedrick, E.; Lee, S.-O.; Doddapaneni, R.; Singh, M.; Safe, S. Nuclear receptor 4A1 as a drug target for breast cancer chemotherapy. Endocr. Relat. Cancer 2015, 22, 831-840. [CrossRef] [PubMed]

83. Alexopoulou, A.N.; Leao, M.; Caballero, O.L.; Da Silva, L.; Reid, L.; Lakhani, S.R.; Simpson, A.J.; Marshall, J.F.; Neville, A.M.; Jat, P.S. Dissecting the transcriptional networks underlying breast cancer: NR4A1 reduces the migration of normal and breast cancer cell lines. Breast Cancer Res. 2010, 12. [CrossRef] [PubMed]

84. Wang, J.; Yang, J.; Zou, Y.; Huang, G.-L.; He, Z.-W. Orphan Nuclear Receptor Nurr1 as a Potential Novel Marker for Progression in Human Prostate Cancer. Asian Pac. J. Cancer Prev. 2013, 14, 2023-2028. [CrossRef] [PubMed]

85. Shan, Z.; Hou, Q.; Zhang, N.A.N.; Guo, L.; Zhang, X.; Ma, Y.; Zhou, Y. Overexpression of oxidored-nitro domain containing protein 1 induces growth inhibition and apoptosis in human prostate cancer PC3 cells. Oncol. Rep. 2014, 32, 1939-1946. [CrossRef] [PubMed]

86. Qin, L.; Zhao, D.; Xu, J.; Ren, X.; Terwilliger, E.F.; Parangi, S.; Lawler, J.; Dvorak, H.F.; Zeng, H. The vascular permeabilizing factors histamine and serotonin induce angiogenesis through TR3/Nur77 and subsequently truncate it through thrombospondin-1. Blood 2013, 121, 2154-2164. [CrossRef] [PubMed]

87. Liu, L.; Yao, J.; Li, Z.; Zu, G.; Feng, D.; Li, Y.; Qasim, W.; Zhang, S.; Li, T.; Zeng, H.; et al. miR-381-3p knockdown improves intestinal epithelial proliferation and barrier function after intestinal ischemia/reperfusion injury by targeting nurr1. Cell Death Dis. 2018, 9. [CrossRef]

88. Ding, L.-J.; Yan, G.-J.; Ge, Q.-Y.; Yu, F.; Zhao, X.; Diao, Z.-Y.; Wang, Z.-Q.; Yang, Z.-Z.; Sun, H.-X.; Hu, Y.-L. FSH acts on the proliferation of type A spermatogonia via Nur77 that increases GDNF expression in the Sertoli cells. FEBS Lett. 2011, 585, 2437-2444. [CrossRef]

89. Mix, K.S.; McMahon, K.; McMorrow, J.P.; Walkenhorst, D.E.; Smyth, A.M.; Petrella, B.L.; Gogarty, M.; Fearon, U.; Veale, D.; Attur, M.G.; et al. Orphan nuclear receptor NR4A2 induces synoviocyte proliferation, invasion and matrix metalloproteinase 13 transcription. Arthritis Rheum. 2012, 64, 2126-2136. [CrossRef]

90. Maijenburg, M.W.; Gilissen, C.; Melief, S.M.; Kleijer, M.; Weijer, K.; ten Brinke, A.; Roelofs, H.; Van Tiel, C.M.; Veltman, J.A.; de Vries, C.J.M.; et al. Nuclear Receptors Nur77 and Nurr1 Modulate Mesenchymal Stromal Cell Migration. Stem Cells Dev. 2012, 21, 228-238. [CrossRef]

91. Vergaño-Vera, E.; Díaz-Guerra, E.; Rodríguez-Traver, E.; Méndez-Gómez, H.R.; Solís, Ó.; Pignatelli, J.; Pickel, J.; Lee, S.-H.; Moratalla, R.; Vicario-Abejón, C. Nurr1 blocks the mitogenic effect of FGF-2 and EGF, inducing olfactory bulb neural stem cells to adopt dopaminergic and dopaminergic-GABAergic neuronal phenotypes. Dev. Neurobiol. 2014, 75, 823-841. [CrossRef] [PubMed]

92. Kim, J.-i.; Jeon, S.G.; Kim, K.A.; Kim, Y.J.; Song, E.J.; Choi, J.; Ahn, K.J.; Kim, C.-J.; Chung, H.Y.; Moon, M.; et al. The pharmacological stimulation of Nurr1 improves cognitive functions via enhancement of adult hippocampal neurogenesis. Stem Cell Res. 2016, 17, 534-543. [CrossRef] [PubMed]

93. Zhu, W.; Cowie, A.; Wasfy, G.W.; Penn, L.Z.; Leber, B.; Andrews, D.W. Bcl-2 mutants with restricted subcellular location reveal spatially distinct pathways for apoptosis in different cell types. Embo. J. 1996, 15, 4130-4141. [CrossRef] [PubMed]

94. Goldar, S.; Khaniani, M.S.; Derakhshan, S.M.; Baradaran, B. Molecular mechanisms of apoptosis and roles in cancer development and treatment. Asian Pac. J. Cancer Prev. 2015, 16, 2129-2144. [CrossRef] [PubMed]

95. Kim, B.Y.; Kim, H.; Cho, E.J.; Youn, H.D. Nur77 upregulates HIF-alpha by inhibiting pVHL-mediated degradation. Exp. Mol. Med. 2008, 40,71-83. [CrossRef]

96. Strasser, A. The role of BH3-only proteins in the immune system. Nat. Rev. Immunol. 2005, 5, 189-200. [CrossRef]

97. Simon, H.U.; Haj-Yehia, A.; Levi-Schaffer, F. Role of reactive oxygen species (ROS) in apoptosis induction. Apoptosis 2000, 5, 415-418. [CrossRef]

98. Redza-Dutordoir, M.; Averill-Bates, D.A. Activation of apoptosis signalling pathways by reactive oxygen species. Biochim. Biophys. Acta 2016, 1863, 2977-2992. [CrossRef]

99. Kudo, N.; Matsumori, N.; Taoka, H.; Fujiwara, D.; Schreiner, E.P.; Wolff, B.; Yoshida, M.; Horinouchi, S. Leptomycin B inactivates CRM1/exportin 1 by covalent modification at a cysteine residue in the central conserved region. Proc. Natl. Acad. Sci. United States Am. 1999, 96, 9112-9117. [CrossRef] 
100. Leevers, S.J.; Paterson, H.F.; Marshall, C.J. Requirement for Ras in Raf activation is overcome by targeting Raf to the plasma membrane. Nature 1994, 369, 411-414. [CrossRef]

101. Yu, H.; Kumar, S.M.; Fang, D.; Acs, G.; Xu, X. Nuclear orphan receptor TR3/Nur77 mediates melanoma cell apoptosis. Cancer Biol. 2007, 6, 405-412. [CrossRef] [PubMed]

102. Cheng, Z.; Volkers, M.; Din, S.; Avitabile, D.; Khan, M.; Gude, N.; Mohsin, S.; Bo, T.; Truffa, S.; Alvarez, R.; et al. Mitochondrial translocation of Nur77 mediates cardiomyocyte apoptosis. Eur. Heart J. 2011, 32, 2179-2188. [CrossRef] [PubMed]

103. Zhao, B.X.; Chen, H.Z.; Du, X.D.; Luo, J.; He, J.P.; Wang, R.H.; Wang, Y.; Wu, R.; Hou, R.R.; Hong, M.; et al. Orphan receptor TR3 enhances p53 transactivation and represses DNA double-strand break repair in hepatoma cells under ionizing radiation. Mol. Endocrinol. 2011, 25, 1337-1350. [CrossRef] [PubMed]

104. Alonso, J.; Galan, M.; Marti-Pamies, I.; Romero, J.M.; Camacho, M.; Rodriguez, C.; Martinez-Gonzalez, J. NOR-1/NR4A3 regulates the cellular inhibitor of apoptosis 2 (cIAP2) in vascular cells: Role in the survival response to hypoxic stress. Sci. Rep. 2016, 6, 34056. [CrossRef]

105. Yu, C.; Cui, S.; Zong, C.; Gao, W.; Xu, T.; Gao, P.; Chen, J.; Qin, D.; Guan, Q.; Liu, Y.; et al. The Orphan Nuclear Receptor NR4A1 Protects Pancreatic beta-Cells from Endoplasmic Reticulum (ER) Stress-mediated Apoptosis. J. Biol. Chem. 2015, 290, 20687-20699. [CrossRef]

106. Zong, C.; Qin, D.; Yu, C.; Gao, P.; Chen, J.; Lu, S.; Zhang, Y.; Liu, Y.; Yang, Y.; Pu, Z.; et al. The stress-response molecule NR4A1 resists ROS-induced pancreatic beta-cells apoptosis via WT1. Cell Signal 2017, 35, 129-139. [CrossRef]

107. Toth, B.; Ludanyi, K.; Kiss, I.; Reichert, U.; Michel, S.; Fesus, L.; Szondy, Z. Retinoids induce Fas(CD95) ligand cell surface expression via RARgamma and nur77 in T cells. Eur. J. Immunol. 2004, 34, 827-836. [CrossRef]

108. Volakakis, N.; Kadkhodaei, B.; Joodmardi, E.; Wallis, K.; Panman, L.; Silvaggi, J.; Spiegelman, B.M.; Perlmann, T. NR4A orphan nuclear receptors as mediators of CREB-dependent neuroprotection. Proc. Natl. Acad. Sci. United States Am. 2010, 107, 12317-12322. [CrossRef]

109. Shimizu, Y.; Miyakura, R.; Otsuka, Y. Nuclear receptor subfamily 4, group A, member 1 inhibits extrinsic apoptosis and reduces caspase-8 activity in H2O2-induced human HUC-F2 fibroblasts. Redox Rep. 2015, 20, 81-88. [CrossRef]

110. Chen, H.Z.; Wen, Q.; Wang, W.J.; He, J.P.; Wu, Q. The orphan nuclear receptor TR3/Nur77 regulates ER stress and induces apoptosis via interaction with TRAPgamma. Int. J. Biochem. Cell Biol. 2013, 45, 1600-1609. [CrossRef]

111. Ohkura, N.; Nagamura, Y.; Tsukada, T. Differential transactivation by orphan nuclear receptor NOR1 and its fusion gene product EWS/NOR1: Possible involvement of poly(ADP-ribose) polymerase I, PARP-1. J. Cell Biochem. 2008, 105, 785-800. [CrossRef] [PubMed]

112. Munnur, D.; Somers, J.; Skalka, G.; Weston, R.; Jukes-Jones, R.; Bhogadia, M.; Dominguez, C.; Cain, K.; Ahel, I.; Malewicz, M. NR4A Nuclear Receptors Target Poly-ADP-Ribosylated DNA-PKcs Protein to Promote DNA Repair. Cell Rep. 2019, 26, 2028-2036. [CrossRef] [PubMed]

113. Nair, P.; Lu, M.; Petersen, S.; Ashkenazi, A. Apoptosis initiation through the cell-extrinsic pathway. Methods Enzym. 2014, 544, 99-128. [CrossRef]

114. Movassagh, M.; Foo, R.S. Simplified apoptotic cascades. Heart Fail. Rev. 2008, 13, 111-119. [CrossRef]

115. Hotchkiss, R.S.; Strasser, A.; McDunn, J.E.; Swanson, P.E. Cell death. N Engl. J. Med. 2009, 361, $1570-1583$. [CrossRef]

116. Thomas, H.E.; McKenzie, M.D.; Angstetra, E.; Campbell, P.D.; Kay, T.W. Beta cell apoptosis in diabetes. Apoptosis 2009, 14, 1389-1404. [CrossRef]

117. Wake, K. Perisinusoidal stellate cells (fat-storing cells, interstitial cells, lipocytes), their related structure in and around the liver sinusoids and vitamin A-storing cells in extrahepatic organs. Int. Rev. Cytol. 1980, 66, 303-353. [CrossRef]

118. Karaskov, E.; Scott, C.; Zhang, L.; Teodoro, T.; Ravazzola, M.; Volchuk, A. Chronic palmitate but not oleate exposure induces endoplasmic reticulum stress, which may contribute to INS-1 pancreatic beta-cell apoptosis. Endocrinology 2006, 147, 3398-3407. [CrossRef]

119. Gwiazda, K.S.; Yang, T.L.; Lin, Y.; Johnson, J.D. Effects of palmitate on ER and cytosolic Ca2+ homeostasis in beta-cells. Am J. Physiol. Endocrinol. Metab. 2009, 296, E690-E701. [CrossRef]

120. Jaiswal, P.K.; Goel, A.; Mittal, R.D. Survivin: A molecular biomarker in cancer. Indian J. Med. Res. 2015, 141, 389-397. [CrossRef] 
121. Cnop, M.; Welsh, N.; Jonas, J.C.; Jorns, A.; Lenzen, S.; Eizirik, D.L. Mechanisms of pancreatic beta-cell death in type 1 and type 2 diabetes: Many differences, few similarities. Diabetes 2005, 54 Suppl. 2, S97-S107. [CrossRef]

122. Steppel, J.H.; Horton, E.S. Beta-cell failure in the pathogenesis of type 2 diabetes mellitus. Curr. Diab. Rep. 2004, 4, 169-175. [CrossRef] [PubMed]

123. Laybutt, D.R.; Preston, A.M.; Akerfeldt, M.C.; Kench, J.G.; Busch, A.K.; Biankin, A.V.; Biden, T.J. Endoplasmic reticulum stress contributes to beta cell apoptosis in type 2 diabetes. Diabetologia 2007, 50, 752-763. [CrossRef] [PubMed]

124. Tajiri, Y.; Moller, C.; Grill, V. Long-term effects of aminoguanidine on insulin release and biosynthesis: Evidence that the formation of advanced glycosylation end products inhibits B cell function. Endocrinology 1997, 138, 273-280. [CrossRef] [PubMed]

125. Cai, J.; Yang, J.; Jones, D.P. Mitochondrial control of apoptosis: The role of cytochrome c. Biochim. Biophys. Acta 1998, 1366, 139-149. [CrossRef]

126. Jiang, X.; Wang, X. Cytochrome C-mediated apoptosis. Annu. Rev. Biochem. 2004, 73, 87-106. [CrossRef]

127. Huttemann, M.; Pecina, P.; Rainbolt, M.; Sanderson, T.H.; Kagan, V.E.; Samavati, L.; Doan, J.W.; Lee, I. The multiple functions of cytochrome $\mathrm{c}$ and their regulation in life and death decisions of the mammalian cell: From respiration to apoptosis. Mitochondrion 2011, 11, 369-381. [CrossRef]

128. Li, H.; Kolluri, S.K.; Gu, J.; Dawson, M.I.; Cao, X.; Hobbs, P.D.; Lin, B.; Chen, G.; Lu, J.; Lin, F.; et al. Cytochrome c release and apoptosis induced by mitochondrial targeting of nuclear orphan receptor TR3. Science 2000, 289, 1159-1164. [CrossRef]

129. Lin, B.; Kolluri, S.K.; Lin, F.; Liu, W.; Han, Y.H.; Cao, X.; Dawson, M.I.; Reed, J.C.; Zhang, X.K. Conversion of Bcl-2 from protector to killer by interaction with nuclear orphan receptor Nur77/TR3. Cell 2004, 116, 527-540. [CrossRef]

130. Chen, H.Z.; Zhao, B.X.; Zhao, W.X.; Li, L.; Zhang, B.; Wu, Q. Akt phosphorylates the TR3 orphan receptor and blocks its targeting to the mitochondria. Carcinogenesis 2008, 29, 2078-2088. [CrossRef]

131. Zhan, Y.Y.; Wu, Q. Translocation of orphan receptor TR3 from nuclei to mitochondria induced by staurosporine. Ai Zheng 2004, 23, 1593-1598. [PubMed]

132. Sun, Z.; Cao, X.; Jiang, M.M.; Qiu, Y.; Zhou, H.; Chen, L.; Qin, B.; Wu, H.; Jiang, F.; Chen, J.; et al. Inhibition of beta-catenin signaling by nongenomic action of orphan nuclear receptor Nur77. Oncogene 2012, 31, 2653-2667. [CrossRef]

133. Gill, G. Post-translational modification by the small ubiquitin-related modifier SUMO has big effects on transcription factor activity. Curr. Opin. Genet. Dev. 2003, 13, 108-113. [CrossRef]

134. Bode, A.M.; Dong, Z. Post-translational modification of p53 in tumorigenesis. Nat. Rev. Cancer 2004, 4, 793-805. [CrossRef]

135. Han, Y.H.; Cao, X.; Lin, B.; Lin, F.; Kolluri, S.K.; Stebbins, J.; Reed, J.C.; Dawson, M.I.; Zhang, X.K. Regulation of Nur77 nuclear export by c-Jun N-terminal kinase and Akt. Oncogene 2006, 25, 2974-2986. [CrossRef]

136. Hirata, Y.; Kiuchi, K.; Chen, H.C.; Milbrandt, J.; Guroff, G. The phosphorylation and DNA binding of the DNA-binding domain of the orphan nuclear receptor NGFI-B. J. Biol. Chem. 1993, 268, 24808-24812.

137. Katagiri, Y.; Takeda, K.; Yu, Z.X.; Ferrans, V.J.; Ozato, K.; Guroff, G. Modulation of retinoid signalling through NGF-induced nuclear export of NGFI-B. Nat. Cell Biol. 2000, 2, 435-440. [CrossRef]

138. Deutsch, A.J.; Rinner, B.; Wenzl, K.; Pichler, M.; Troppan, K.; Steinbauer, E.; Schwarzenbacher, D.; Reitter, S.; Feichtinger, J.; Tierling, S.; et al. NR4A1-mediated apoptosis suppresses lymphomagenesis and is associated with a favorable cancer-specific survival in patients with aggressive B-cell lymphomas. Blood 2014, 123, 2367-2377. [CrossRef]

139. Fechter, K.; Feichtinger, J.; Prochazka, K.; Unterluggauer, J.J.; Pansy, K.; Steinbauer, E.; Pichler, M.; Haybaeck, J.; Prokesch, A.; Greinix, H.T.; et al. Cytoplasmic location of NR4A1 in aggressive lymphomas is associated with a favourable cancer specific survival. Sci. Rep. 2018, 8, 14528. [CrossRef]

140. Fedorova, O.; Petukhov, A.; Daks, A.; Shuvalov, O.; Leonova, T.; Vasileva, E.; Aksenov, N.; Melino, G.; Barlev, N.A. Orphan receptor NR4A3 is a novel target of p53 that contributes to apoptosis. Oncogene 2019, 38, 2108-2122. [CrossRef]

141. Jin, Z.; El-Deiry, W.S. Overview of cell death signaling pathways. Cancer Biol. 2005, 4, 139-163. [CrossRef] [PubMed]

142. Boatright, K.M.; Salvesen, G.S. Mechanisms of caspase activation. Curr. Opin. Cell Biol. 2003, 15, 725-731. [CrossRef] [PubMed] 
143. Khosravi-Far, R.; Esposti, M.D. Death receptor signals to mitochondria. Cancer Biol. 2004, 3, $1051-1057$. [CrossRef] [PubMed]

144. Silke, J.; Meier, P. Inhibitor of apoptosis (IAP) proteins-modulators of cell death and inflammation. Cold Spring Harb Perspect Biol. 2013, 5. [CrossRef] [PubMed]

145. Lawlor, K.E.; Feltham, R.; Yabal, M.; Conos, S.A.; Chen, K.W.; Ziehe, S.; Grass, C.; Zhan, Y.; Nguyen, T.A.; Hall, C.; et al. XIAP Loss Triggers RIPK3- and Caspase-8-Driven IL-1beta Activation and Cell Death as a Consequence of TLR-MyD88-Induced cIAP1-TRAF2 Degradation. Cell Rep. 2017, 20, 668-682. [CrossRef] [PubMed]

146. Calnan, B.J.; Szychowski, S.; Chan, F.K.; Cado, D.; Winoto, A. A role for the orphan steroid receptor Nur77 in apoptosis accompanying antigen-induced negative selection. Immunity 1995, 3, 273-282. [CrossRef]

147. Liu, X.; Wang, Y.; Lu, H.; Li, J.; Yan, X.; Xiao, M.; Hao, J.; Alekseev, A.; Khong, H.; Chen, T.; et al. Genome-wide analysis identifies NR4A1 as a key mediator of T cell dysfunction. Nature 2019, 567, 525-529. [CrossRef]

148. Kristie, T.M.; Roizman, B. DNA-binding site of major regulatory protein alpha 4 specifically associated with promoter-regulatory domains of alpha genes of herpes simplex virus type 1. Proc. Natl. Acad. Sci. United States Am. 1986, 83, 4700-4704. [CrossRef]

149. Kim, Y.C.; Song, S.B.; Lee, M.H.; Kang, K.I.; Lee, H.; Paik, S.G.; Kim, K.E.; Kim, Y.S. Simvastatin induces caspase-independent apoptosis in LPS-activated RAW264.7 macrophage cells. Biochem. Biophys. Res. Commun. 2006, 339, 1007-1014. [CrossRef]

150. Kim, Y.D.; Kim, S.G.; Hwang, S.L.; Choi, H.S.; Bae, J.H.; Song, D.K.; Im, S.S. B-cell translocation gene 2 regulates hepatic glucose homeostasis via induction of orphan nuclear receptor Nur77 in diabetic mouse model. Diabetes 2014, 63, 1870-1880. [CrossRef]

151. Kim, Y.C.; Song, S.B.; Lee, S.K.; Park, S.M.; Kim, Y.S. The Nuclear Orphan Receptor NR4A1 is Involved in the Apoptotic Pathway Induced by LPS and Simvastatin in RAW 264.7 Macrophages. Immune Netw. 2014, 14, 116-122. [CrossRef] [PubMed]

152. Davila, M.L.; Riviere, I.; Wang, X.; Bartido, S.; Park, J.; Curran, K.; Chung, S.S.; Stefanski, J.; Borquez-Ojeda, O.; Olszewska, M.; et al. Efficacy and toxicity management of 19-28z CAR T cell therapy in B cell acute lymphoblastic leukemia. Sci. Transl. Med. 2014, 6, 224ra225. [CrossRef] [PubMed]

153. Schietinger, A.; Greenberg, P.D. Tolerance and exhaustion: Defining mechanisms of T cell dysfunction. Trends Immunol. 2014, 35, 51-60. [CrossRef] [PubMed]

154. Chen, J.; Lopez-Moyado, I.F.; Seo, H.; Lio, C.J.; Hempleman, L.J.; Sekiya, T.; Yoshimura, A.; Scott-Browne, J.P.; Rao, A. NR4A transcription factors limit CAR T cell function in solid tumours. Nature 2019, 567, 530-534. [CrossRef] [PubMed]

155. Lee, S.O.; Andey, T.; Jin, U.H.; Kim, K.; Singh, M.; Safe, S. The nuclear receptor TR3 regulates mTORC1 signaling in lung cancer cells expressing wild-type p53. Oncogene 2012, 31, 3265-3276. [CrossRef]

156. Lee, S.O.; Jin, U.H.; Kang, J.H.; Kim, S.B.; Guthrie, A.S.; Sreevalsan, S.; Lee, J.S.; Safe, S. The orphan nuclear receptor NR4A1 (Nur77) regulates oxidative and endoplasmic reticulum stress in pancreatic cancer cells. Mol. Cancer Res. 2014, 12, 527-538. [CrossRef]

157. Ishizawa, M.; Kagechika, H.; Makishima, M. NR4A nuclear receptors mediate carnitine palmitoyltransferase 1A gene expression by the rexinoid HX600. Biochem. Biophys. Res. Commun. 2012, 418, 780-785. [CrossRef]

158. Chao, L.C.; Wroblewski, K.; Ilkayeva, O.R.; Stevens, R.D.; Bain, J.; Meyer, G.A.; Schenk, S.; Martinez, L.; Vergnes, L.; Narkar, V.A.; et al. Skeletal muscle Nur77 expression enhances oxidative metabolism and substrate utilization. J. Lipid Res. 2012, 53, 2610-2619. [CrossRef]

159. Li, X.X.; Wang, Z.J.; Zheng, Y.; Guan, Y.F.; Yang, P.B.; Chen, X.; Peng, C.; He, J.P.; Ai, Y.L.; Wu, S.F.; et al. Nuclear Receptor Nur77 Facilitates Melanoma Cell Survival under Metabolic Stress by Protecting Fatty Acid Oxidation. Mol. Cell 2018, 69, 480-492. [CrossRef]

160. Maxwell, M.A.; Cleasby, M.E.; Harding, A.; Stark, A.; Cooney, G.J.; Muscat, G.E. Nur77 regulates lipolysis in skeletal muscle cells. Evidence for cross-talk between the beta-adrenergic and an orphan nuclear hormone receptor pathway. J. Biol. Chem. 2005, 280, 12573-12584. [CrossRef]

161. Holla, V.R.; Wu, H.; Shi, Q.; Menter, D.G.; DuBois, R.N. Nuclear orphan receptor NR4A2 modulates fatty acid oxidation pathways in colorectal cancer. J. Biol. Chem. 2011, 286, 30003-30009. [CrossRef] [PubMed]

162. Perez-Sieira, S.; Martinez, G.; Porteiro, B.; Lopez, M.; Vidal, A.; Nogueiras, R.; Dieguez, C. Female Nur77-deficient mice show increased susceptibility to diet-induced obesity. PLoS ONE 2013, 8, e53836. [CrossRef] 
163. Praslicka, B.; Harmson, J.S.; Kim, J.; Rangaraj, V.R.; Ooi, A.; Gissendanner, C.R. Binding Site Analysis of the Caenorhabditis Elegans Nr4a Nuclear Receptor Nhr-6 during Development. Nucl. Recept. Res. 2017, 4. [CrossRef] [PubMed]

164. Jung, Y.S.; Lee, H.S.; Cho, H.R.; Kim, K.J.; Kim, J.H.; Safe, S.; Lee, S.O. Dual targeting of Nur77 and AMPKalpha by isoalantolactone inhibits adipogenesis in vitro and decreases body fat mass in vivo. Int. J. Obes. 2019, 43, 952-962. [CrossRef] [PubMed]

165. Stephenson, E.J.; Stepto, N.K.; Koch, L.G.; Britton, S.L.; Hawley, J.A. Divergent skeletal muscle respiratory capacities in rats artificially selected for high and low running ability: A role for Nor1? J. Appl. Physiol. 2012, 113, 1403-1412. [CrossRef]

166. Pearen, M.A.; Goode, J.M.; Fitzsimmons, R.L.; Eriksson, N.A.; Thomas, G.P.; Cowin, G.J.; Wang, S.C.; Tuong, Z.K.; Muscat, G.E. Transgenic muscle-specific Nor-1 expression regulates multiple pathways that effect adiposity, metabolism and endurance. Mol. Endocrinol. 2013, 27, 1897-1917. [CrossRef]

167. Zhang, Y.; Federation, A.J.; Kim, S.; O’Keefe, J.P.; Lun, M.; Xiang, D.; Brown, J.D.; Steinhauser, M.L. Targeting nuclear receptor NR4A1-dependent adipocyte progenitor quiescence promotes metabolic adaptation to obesity. J. Clin. Invest. 2018, 128, 4898-4911. [CrossRef]

168. Mohankumar, K.; Lee, J.; Wu, C.S.; Sun, Y.; Safe, S. Bis-Indole-Derived NR4A1 Ligands and Metformin Exhibit NR4A1-Dependent Glucose Metabolism and Uptake in C2C12 Cells. Endocrinology 2018, 159, 1950-1963. [CrossRef]

169. Qin, D.D.; Yang, Y.F.; Pu, Z.Q.; Liu, D.; Yu, C.; Gao, P.; Chen, J.C.; Zong, C.; Zhang, Y.C.; Li, X.; et al. NR4A1 retards adipocyte differentiation or maturation via enhancing GATA2 and p53 expression. J. Cell Mol. Med. 2018, 22, 4709-4720. [CrossRef]

170. Lehmann, L.H.; Jebessa, Z.H.; Kreusser, M.M.; Horsch, A.; He, T.; Kronlage, M.; Dewenter, M.; Sramek, V.; Oehl, U.; Krebs-Haupenthal, J.; et al. A proteolytic fragment of histone deacetylase 4 protects the heart from failure by regulating the hexosamine biosynthetic pathway. Nat. Med. 2018, 24, 62-72. [CrossRef]

171. Pearen, M.A.; Eriksson, N.A.; Fitzsimmons, R.L.; Goode, J.M.; Martel, N.; Andrikopoulos, S.; Muscat, G.E. The nuclear receptor, Nor-1, markedly increases type II oxidative muscle fibers and resistance to fatigue. Mol. Endocrinol. 2012, 26, 372-384. [CrossRef] [PubMed]

172. Zhan, Y.; Du, X.; Chen, H.; Liu, J.; Zhao, B.; Huang, D.; Li, G.; Xu, Q.; Zhang, M.; Weimer, B.C.; et al. Cytosporone B is an agonist for nuclear orphan receptor Nur77. Nat. Chem. Biol. 2008, 4, 548-556. [CrossRef] [PubMed]

173. Li, X.; Xu, M.; Wang, F.; Ji, Y.; Davidso, N.W.; Li, Z.; Tso, P. Interaction of ApoA-IV with NR4A1 and NR1D1 Represses G6Pase and PEPCK Transcription: Nuclear Receptor-Mediated Downregulation of Hepatic Gluconeogenesis in Mice and a Human Hepatocyte Cell Line. PLoS ONE 2015, 10, e0142098. [CrossRef] [PubMed]

174. Fu, Y.; Luo, L.; Luo, N.; Zhu, X.; Garvey, W.T. NR4A orphan nuclear receptors modulate insulin action and the glucose transport system: Potential role in insulin resistance. J. Biol. Chem. 2007, 282, 31525-31533. [CrossRef]

175. Zhou, H.; Du, W.; Li, Y.; Shi, C.; Hu, N.; Ma, S.; Wang, W.; Ren, J. Effects of melatonin on fatty liver disease: The role of NR4A1/DNA-PKcs/p53 pathway, mitochondrial fission and mitophagy. J. Pineal. Res. 2018, 64. [CrossRef]

176. Veum, V.L.; Dankel, S.N.; Gjerde, J.; Nielsen, H.J.; Solsvik, M.H.; Haugen, C.; Christensen, B.J.; Hoang, T.; Fadnes, D.J.; Busch, C.; et al. The nuclear receptors NUR77, NURR1 and NOR1 in obesity and during fat loss. Int J. Obes. 2012, 36, 1195-1202. [CrossRef]

177. Maris, M.; Waelkens, E.; Cnop, M.; D’Hertog, W.; Cunha, D.A.; Korf, H.; Koike, T.; Overbergh, L.; Mathieu, C. Oleate-induced beta cell dysfunction and apoptosis: A proteomic approach to glucolipotoxicity by an unsaturated fatty acid. J. Proteome Res. 2011, 10, 3372-3385. [CrossRef]

178. Kanzleiter, T.; Schneider, T.; Walter, I.; Bolze, F.; Eickhorst, C.; Heldmaier, G.; Klaus, S.; Klingenspor, M. Evidence for Nr4a1 as a cold-induced effector of brown fat thermogenesis. Physiol. Genom. 2005, 24, 37-44. [CrossRef]

179. Briand, O.; Helleboid-Chapman, A.; Ploton, M.; Hennuyer, N.; Carpentier, R.; Pattou, F.; Vandewalle, B.; Moerman, E.; Gmyr, V.; Kerr-Conte, J.; et al. The nuclear orphan receptor Nur77 is a lipotoxicity sensor regulating glucose-induced insulin secretion in pancreatic beta-cells. Mol. Endocrinol. 2012, 26, 399-413. [CrossRef] 
180. Koenis, D.S.; Medzikovic, L.; van Loenen, P.B.; van Weeghel, M.; Huveneers, S.; Vos, M.; Evers-van Gogh, I.J.; Van den Bossche, J.; Speijer, D.; Kim, Y.; et al. Nuclear Receptor Nur77 Limits the Macrophage Inflammatory Response through Transcriptional Reprogramming of Mitochondrial Metabolism. Cell Rep. 2018, 24, 2127-2140. [CrossRef]

181. Corrocher, F.A.; Bueno de Paiva, L.; Duarte, A.S.S.; Ferro, K.P.; Silveira, L.D.R.; de Lima, T.I.; Olalla Saad, S.T.; Lazarini, M. Reduced expression of NR4A1 activates glycolytic pathway in acute promyelocytic leukemia cells. Leuk. Lymphoma 2018, 59, 1501-1504. [CrossRef] [PubMed]

182. Roche, E.; Buteau, J.; Aniento, I.; Reig, J.A.; Soria, B.; Prentki, M. Palmitate and oleate induce the immediate-early response genes c-fos and nur-77 in the pancreatic beta-cell line INS-1. Diabetes 1999, 48, 2007-2014. [CrossRef] [PubMed]

183. Fassett, M.S.; Jiang, W.; D'Alise, A.M.; Mathis, D.; Benoist, C. Nuclear receptor Nr4a1 modulates both regulatory T-cell (Treg) differentiation and clonal deletion. Proc. Natl. Acad. Sci. USA 2012, 109, 3891-3896. [CrossRef] [PubMed]

184. Pei, L.; Waki, H.; Vaitheesvaran, B.; Wilpitz, D.C.; Kurland, I.J.; Tontonoz, P. NR4A orphan nuclear receptors are transcriptional regulators of hepatic glucose metabolism. Nat. Med. 2006, 12, 1048-1055. [CrossRef]

185. Navarro, M.A.; Badimon, L.; Rodriguez, C.; Arnal, C.; Noone, E.J.; Roche, H.M.; Osada, J.; Martinez-Gonzalez, J. Trans-10,cis-12-CLA dysregulate lipid and glucose metabolism and induce hepatic NR4A receptors. Front Biosci. 2010, 2, 87-97.

186. Pols, T.W.; Ottenhoff, R.; Vos, M.; Levels, J.H.; Quax, P.H.; Meijers, J.C.; Pannekoek, H.; Groen, A.K.; de Vries, C.J. Nur77 modulates hepatic lipid metabolism through suppression of SREBP1c activity. Biochem. Biophys. Res. Commun. 2008, 366, 910-916. [CrossRef]

187. Chao, L.C.; Zhang, Z.; Pei, L.; Saito, T.; Tontonoz, P.; Pilch, P.F. Nur77 coordinately regulates expression of genes linked to glucose metabolism in skeletal muscle. Mol. Endocrinol. 2007, 21, 2152-2163. [CrossRef]

188. Cortez-Toledo, O.; Schnair, C.; Sangngern, P.; Metzger, D.; Chao, L.C. Nur77 deletion impairs muscle growth during developmental myogenesis and muscle regeneration in mice. PLoS ONE 2017, 12, e0171268. [CrossRef]

189. Reynolds, M.S.; Hancock, C.R.; Ray, J.D.; Kener, K.B.; Draney, C.; Garland, K.; Hardman, J.; Bikman, B.T.; Tessem, J.S. beta-Cell deletion of Nr4a1 and Nr4a3 nuclear receptors impedes mitochondrial respiration and insulin secretion. Am. J. Physiol. Endocrinol. Metab. 2016, 311, E186-E201. [CrossRef]

190. Liebmann, M.; Hucke, S.; Koch, K.; Eschborn, M.; Ghelman, J.; Chasan, A.I.; Glander, S.; Schadlich, M.; Kuhlencord, M.; Daber, N.M.; et al. Nur77 serves as a molecular brake of the metabolic switch during T cell activation to restrict autoimmunity. Proc. Natl. Acad. Sci. USA 2018, 115, E8017-E8026. [CrossRef]

191. Adhikari, P.; Orozco, D.; Randhawa, H.; Wolf, F.W. Mef2 induction of the immediate early gene Hr38/Nr4a is terminated by Sirt1 to promote ethanol tolerance. Genes Brain Behav. 2019, 18, e12486. [CrossRef] [PubMed]

192. Ruaud, A.F.; Lam, G.; Thummel, C.S. The Drosophila NR4A nuclear receptor DHR38 regulates carbohydrate metabolism and glycogen storage. Mol. Endocrinol. 2011, 25, 83-91. [CrossRef] [PubMed]

193. Miao, L.; Yang, Y.; Liu, Y.; Lai, L.; Wang, L.; Zhan, Y.; Yin, R.; Yu, M.; Li, C.; Yang, X.; et al. Glycerol kinase interacts with nuclear receptor NR4A1 and regulates glucose metabolism in the liver. Faseb J. 2019, 33, 6736-6747. [CrossRef] [PubMed]

194. Au, W.S.; Payne, V.A.; O'Rahilly, S.; Rochford, J.J. The NR4A family of orphan nuclear receptors are not required for adipogenesis. Int. J. Obes. 2008, 32, 388-392. [CrossRef]

195. Kumar, N.; Liu, D.; Wang, H.; Robidoux, J.; Collins, S. Orphan nuclear receptor NOR-1 enhances 3',5'-cyclic adenosine 5'-monophosphate-dependent uncoupling protein-1 gene transcription. Mol. Endocrinol. 2008, 22, 1057-1064. [CrossRef]

(C) 2019 by the authors. Licensee MDPI, Basel, Switzerland. This article is an open access article distributed under the terms and conditions of the Creative Commons Attribution (CC BY) license (http://creativecommons.org/licenses/by/4.0/). 